\title{
Biological albedo reduction on ice sheets, glaciers, and snowfields
}

Scott Hotaling ${ }^{1}$, Stefanie Lutz ${ }^{2}$, Roman J. Dial ${ }^{3}$, Alexandre M. Anesio ${ }^{4}$, Liane G. Benning ${ }^{2,5}$, Andrew G. Fountain ${ }^{6}$, Joanna L. Kelley ${ }^{1}$, Jenine McCutcheon ${ }^{7}$, S. McKenzie Skiles ${ }^{8}$, Nozomu Takeuchi $^{9}$, and Trinity L. Hamilton ${ }^{10}$

\footnotetext{
Affiliations:

${ }^{1}$ School of Biological Sciences, Washington State University, Pullman, WA, USA

${ }^{2}$ GFZ German Research Center for Geosciences, Telegrafenberg, 14473 Potsdam, Germany

${ }^{3}$ Institute of Culture and Environment, Alaska Pacific University, Anchorage, AK, USA

${ }^{4}$ Department of Environmental Science, Aarhus University, 4000 Roskilde, Denmark

${ }^{5}$ Department of Earth Sciences, Free University of Berlin, 12249 Berlin, Germany

${ }^{6}$ Departments of Geology and Geography, Portland State University, Portland, OR, USA

${ }^{7}$ Department of Earth and Environmental Sciences, University of Waterloo, Waterloo, Canada

${ }^{8}$ Department of Geography, University of Utah, Salt Lake City, UT, USA

${ }^{9}$ Department of Earth Sciences, Graduate School of Science, Chiba University, Chiba, Japan

${ }^{10}$ Department of Plant and Microbial Biology and The BioTechnology Institute, University of Minnesota, Saint Paul, MN, USA
}

\section{Correspondence:}

Scott Hotaling, School of Biological Sciences, Washington State University, Pullman, WA, 99164, USA; Email: scott.hotaling@wsu.edu; Phone: (828) 507-9950; ORCID: 0000-0002-59650986

Trinity Hamilton, Department of Plant and Microbial Biology and the BioTechnology Institute, University of Minnesota, Saint Paul, MN, USA; Email: trinityh@umn.edu; Phone: (612) 6256372; ORCID: 0000-0002-2282-4655

Note: This article is a non-peer reviewed preprint submitted to EarthArXiv. It was submitted for peer review to Earth-Science Reviews in January 2021. 


\section{Abstract:}

2 The global cryosphere, Earth's frozen water, is in precipitous decline. The ongoing and

3 predicted impacts of cryosphere loss are diverse, ranging from disappearance of entire biomes

4 to crises of water availability. Covering approximately one-fifth of the Earth, mass loss from the

5 terrestrial cryosphere is driven primarily by a warming atmosphere but reductions in albedo (the

6 proportion of reflected light) also contribute by increasing absorption of solar radiation. In

7 addition to dust and other abiotic impurities, biological communities substantially reduce albedo

8 worldwide. In this review, we provide a global synthesis of biological albedo reduction (BAR) in

9 terrestrial snow and ice ecosystems. We first focus on known drivers-algal blooms and

10 cryoconite (granular sediment on the ice that includes both mineral and biological material)-as

11 they account for much of the biological albedo variability in snow and ice habitats. We then

12 consider an array of potential drivers of BAR whose impacts may be overlooked, such as

13 arthropod deposition, resident organisms (e.g., dark-bodied glacier ice worms), and larger

14 vertebrates, including humans, that visit the cryosphere. We consider both primary (e.g., BAR

15 due to the presence of pigmented algal cells) and indirect (e.g., nutrient addition from arthropod

16 deposition) effects, as well as interactions among biological groups (e.g., birds feeding on ice

17 worms). Collectively, we highlight that in many cases, overlooked drivers and interactions

18 among factors have considerable potential to alter BAR, perhaps rivaling the direct effects of

19 algal blooms and cryoconite. We conclude by highlighting knowledge gaps for the field and

20 detailing a global framework for long-term BAR monitoring.

\section{Introduction:}

23 The global cryosphere — the compilation of Earth's frozen water-is in rapid, accelerating

24 decline (IPCC, 2019). Covering approximately one-fifth of the Earth's surface at present, mass

25 loss from the terrestrial cryosphere is driven primarily by a warming atmosphere (Fountain et al., 26 2012; Hock et al., 2019). Over the last 50 years, spring snow cover on land in the Arctic has 
27 declined by $\sim 13 \%$ per decade and since 2006 , glaciers and ice sheets in Antarctica, Greenland,

28 and elsewhere have lost, in terms of sea level rise, $0.43,0.77$, and $0.61 \mathrm{~mm} \mathrm{yr}^{-1}$, respectively

29 (IPCC, 2019). Beyond physical transformation of the Earth's surface, cryosphere loss impacts

30 climate (Groisman et al., 1994; Hansen and Nazarenko, 2003; Hu and Feng, 2002), ecology

31 (Hotaling et al., 2017b, 2017a), hydrology (Hanzer et al., 2018; Zemp et al., 2019), and society

32 (Milner et al., 2017).

33

34 Among the harshest ecosystems on Earth, ice sheets, glaciers, and snowfields challenge

35 biological communities with low temperatures and limited availability of liquid water and

36 nutrients (Dial et al., 2018; Ganey et al., 2017; Ren et al., 2019). Cryospheric habitats also

37 swing from extreme cold and extended darkness in winter to warm temperatures and intense

38 solar radiation in summer, with biological communities subjected to disruptive freeze-thaw

39 cycles, flooding, and burial by snow (even during the melt season; Hodson et al., 2008;

40 Takeuchi et al., 2006). Nevertheless, diverse communities inhabit perennial snow and ice

41 surfaces (Anesio et al., 2017; Hotaling et al., 2017b), including a range of viruses and

42 microorganisms (e.g., bacteria, archaea, algae, fungi, rotifers; reviewed by Kaczmarek et al.,

43 2015), as well as larger taxa including ice worms (Hotaling et al., 2019a) and birds (Hardy et al., 44 2018).

45

46 Solar radiation warms the Earth. Little of this radiation, however, is absorbed in the atmosphere

47 and instead most is absorbed by the Earth's surface, which in turn warms the atmosphere

48 (Dickinson, 1995). Albedo plays a critical role in the Earth's energy balance by regulating how

49 much solar radiation is reflected or absorbed. Fresh snow has a very high albedo—reflecting

$50>90 \%$ of visible radiation (Skiles et al., 2018)—but during melt, snow grain size and water

51 content increase, which both reduce albedo and cause further melting (Wiscombe and Warren,

52 1980). Both abiotic (e.g., dust) and biotic (e.g., algae) contaminants can also lower snow and 
53 ice albedo, accelerating melt (Skiles et al., 2018). Aspects of the physical environment can also

54 affect albedo, including slope, aspect, and the presence of crevasses and/or supraglacial water;

55 Lin et al., 2014; Ryan et al., 2018; Skiles et al., 2018; Zhang et al., 2018). Thus, albedo plays a

56 central role in cryosphere energy balance and maintenance.

58 The darkening effects of a range of particles, including dust, black carbon, algal blooms, and

59 cryoconite, on the cryosphere can be substantial (Cook et al., 2020b; Kaspari et al., 2015;

60 Musilova et al., 2016; Onuma et al., 2020; Painter et al., 2001, 2007; Perini et al., 2019;

61 Takeuchi et al., 2001a; Takeuchi, 2002; Takeuchi et al., 2018; Williamson et al., 2020; Yallop et

62 al., 2012). For instance, even small amounts ( 10-100 ppb) of black carbon (carbon-rich, abiotic

63 particles produced during hydrocarbon combustion) can decrease albedo by 1-5\% (Grenfell and

64 Light, 2002; Hadley and Kirchstetter, 2012). However, when compared to abiotic factors, the

65 effects of biological albedo reduction (BAR) - the collective influence of biological communities

66 on albedo-have received less attention. Before discussing the known and potential biological

67 factors impacting albedo, we should clarify our use of BAR to define the process rather than

68 "bio-albedo" which has been used previously (e.g., Di Mauro et al., 2020; Onuma et al., 2020).

69 Cook et al. (2020a) argue that bio-albedo is technically incorrect from a remote sensing

70 perspective as biological growth enhances light absorption and thus, a more correct term would

71 be "bio-co-albedo". However, given the interdisciplinary nature of the field and the potential for

72 confusion around the term "co-albedo", Cook et al. (2020a) recommended the field refer to

73 these collective effects as biological albedo reduction (shortened here to BAR; Cook et al.,

74 2020a). We echo this recommendation.

75

76 Blooms of snow and ice algae likely make the most substantial contribution to BAR worldwide

77 (Lutz et al., 2016b; Segawa et al., 2018). During the melt season, algae can dominate surfaces

78 in the terrestrial cryosphere (Cook et al., 2017b, 2017a, 2020b; Ganey et al., 2017; Lutz et al., 
2016b; Ryan et al., 2018; Stibal et al., 2012, 2017; Williamson et al., 2020; Yallop et al., 2012).

80 For instance, over a single summer, red snow algae decreased albedo in the Arctic by as much 81 as $13 \%$ (Lutz et al., 2016b), over $700 \mathrm{~km}^{2}$ of an Alaskan icefield, snow algae increased melt by 82 as much as $\sim 21 \%$ (Ganey et al., 2017), and on the bare ice zone of southwestern Greenland,

83 ice algae can account for $75 \%$ of albedo variability (Cook et al., 2020b; Williamson et al., 2020).

84 Algae, however, are not the only biological factor known to alter albedo. Cryoconite, sediment-

85 based mixtures of biotic communities and minerals, are another global driver of BAR (Baccolo et 86 al., 2017). Beyond algae and cryoconite, a variety of other biological factors have received little

87 to no attention from a BAR perspective but should be considered. These additional factors

88 range from the direct effects of dark-bodied glacier residents (e.g., ice worms) to the indirect

89 effects of nutrients being added by, for example, passive deposition of arthropods and plant 90 material onto snow and ice.

In this review, we consider BAR in the terrestrial cryosphere for both known (e.g., algae, cryoconite) and potential (e.g., invertebrates) drivers (Figs. 1-2). Our overarching goal is to offer

94 a holistic perspective of BAR in the terrestrial cryosphere by considering all of its potential sources—however large or small—and going beyond direct effects (e.g., a pigmented algal cell lowering albedo in situ) to also consider how biological interactions may indirectly alter BAR

97 (with an emphasis on nutrient cycling). We recognize that on a global scale, the influence on

98 BAR for the drivers we highlight varies widely, from well-known, large-scale influencers (e.g., 99 snow and ice algal blooms) to those potentially having negligible effects (e.g., vertebrate travel 100 on snow and ice). Our goal is not to provide a ranking of BAR impacts but rather to encourage 101 future research by highlighting the wide potential for BAR effects. We focus on three major 102 habitats-ice sheets, glaciers, and snowfields—but our conclusions generally apply to related 103 habitats (e.g., seasonal snow, sea ice). Given the interdisciplinary scope of BAR research which 104 includes biology, remote sensing, and, ultimately, physical modeling of the cryosphere and its 
105 future, we specifically focus on the biological component. We begin by synthesizing current 106 knowledge of the known drivers of BAR: snow algae, ice algae, and cryoconite. Next, we 107 highlight potential drivers, ranging from in situ viruses to vertebrate activity and assess the 108 potential for population, community, and ecosystem-level interactions among factors to alter 109 BAR in space and time. We then consider how the effects of climate change-from rising 110 temperatures to altered nutrient dynamics and physical habitat change-may affect BAR. We 111 conclude by highlighting knowledge gaps for the field and detail a framework for a long-term, 112 global monitoring network to improve our collective knowledge of BAR. 


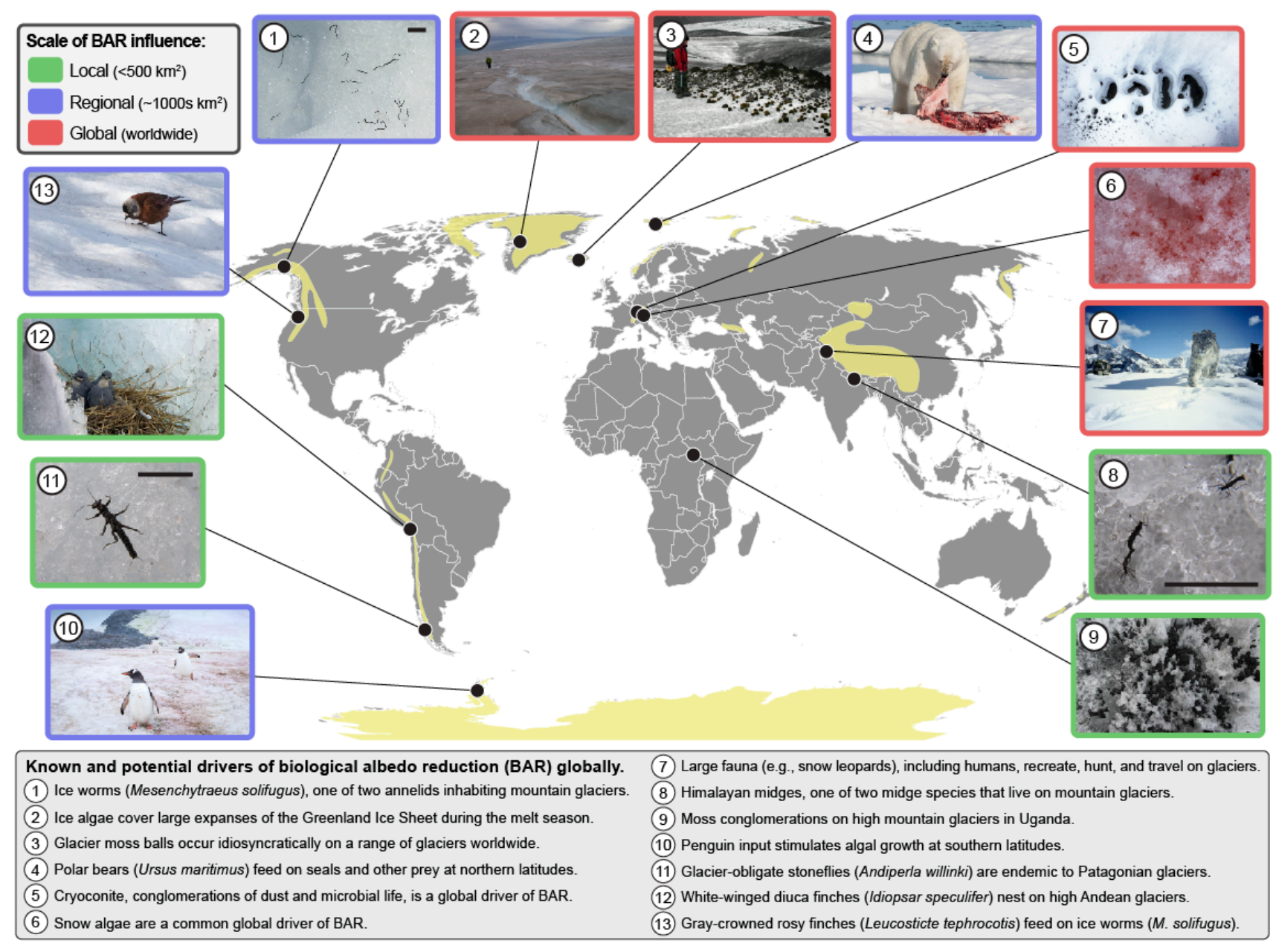

Figure 1. Known and potential drivers of biological albedo reduction (BAR) on ice sheets, glaciers, and snowfields around the world. While all albedo reduction is local in nature, the approximate geographic scale of influence for each driver-the total, non-contiguous area over which they could occur-is given as local, regional, or global. For instance, (1) North American ice worms only occur on coastal glaciers of western North America, thus their BAR influence is regional however (2) ice algae occur on glaciers and ice sheets worldwide and are a global BAR influence. The global distribution of glaciers and ice sheets is shown in yellow [data from the Randolph Glacier Inventory (Pfeffer et al., 2014)]. The black scale bar for invertebrate images represents 1 $\mathrm{cm}$. All other images are $>10 \mathrm{~cm}$ in scale. Photo credits: (1) @ Rachael Mallon, (2) @ Nozomu Takeuchi, (3) @ Nicholas Midgley, (4) @ Andreas Weith/Wikimedia Commons, (5) @ Jürg Alean, (6) @ Serge Ouachée/Wikimedia Commons, (7) @ Snow Leopard Conservancy, (8) @ Shiro Koshima, (9) @ Jun Uetake, (10) @ Acacia Johnson, (11) @ Shiro Koshima, (12) @ BBC NHU, (13) @ Scott Hotaling. 


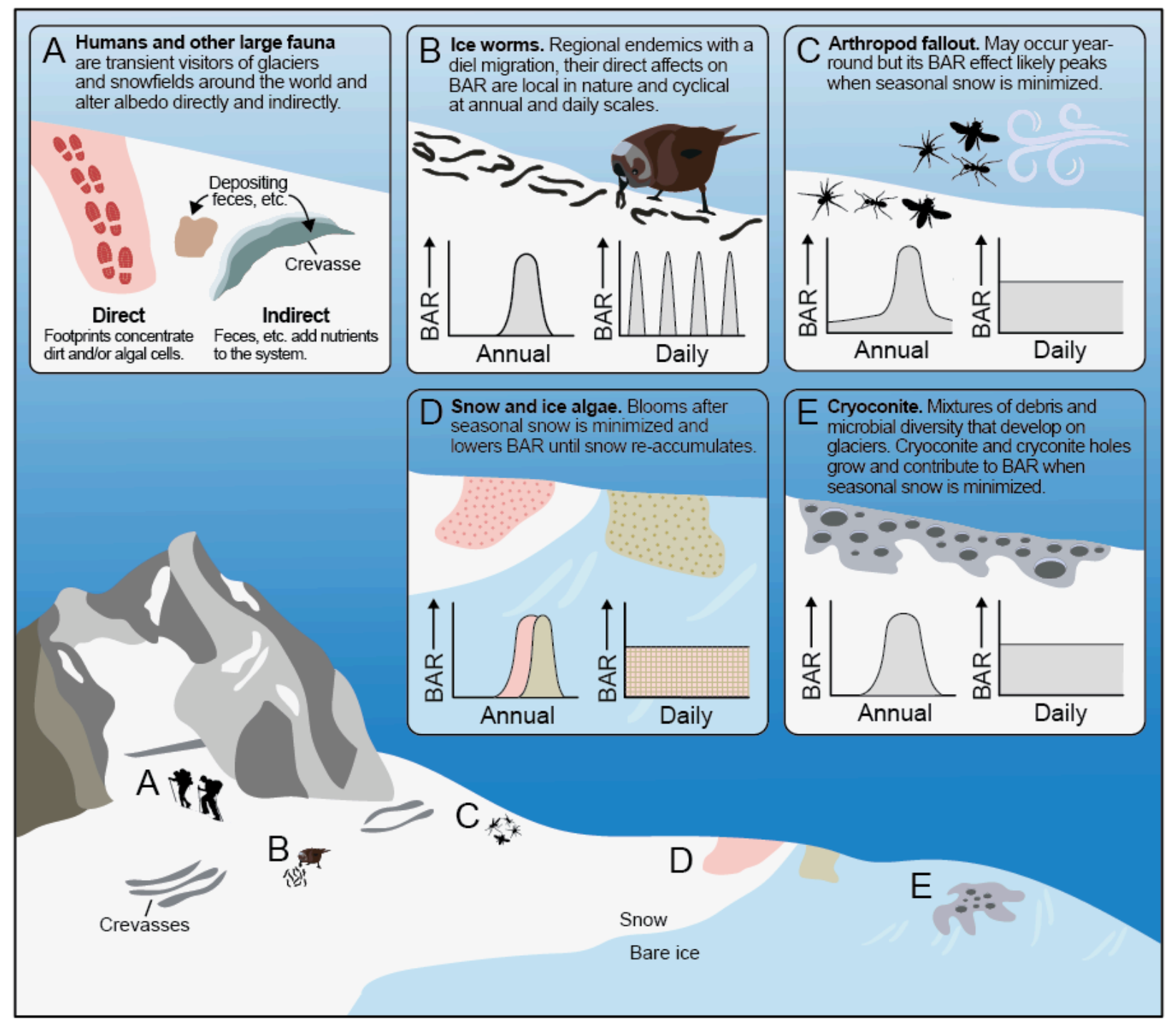

Figure 2. Examples of biological albedo reduction (BAR) on a typical temperate glacier with theoretical plots of each factor's BAR influence on annual and daily timescales where applicable. (A) Humans and other large fauna (e.g., reindeer, birds) contribute to BAR transiently through direct impacts on the snow or ice surface and indirect additions of nutrients, often via feces. (B) Ice worms are regional endemics with diel migrations that attract foraging birds in North America. (C) Arthropods are commonly deposited on glaciers and snowfields by wind, both in regular small amounts (arthropod fallout) and in larger, mass depositions ("bug on snow" events). With limited capacity for survival, the direct effect of arthropods on BAR is constant until they are covered by new snow, consumed by a forager, or decompose. (D) Snow (pink) and ice (tan) algae also contribute to BAR, primarily during the melt season, with snow algal growth on wet snowpack peaking earlier in the season than ice algal growth on bare ice following snow clearance. (E) Cryoconite and cryoconite holes develop on ice sheets and glaciers and their BAR influence peaks when seasonal snow is cleared. Since albedo cannot be calculated at night, inset plots (B-E) only represent daylight hours. 


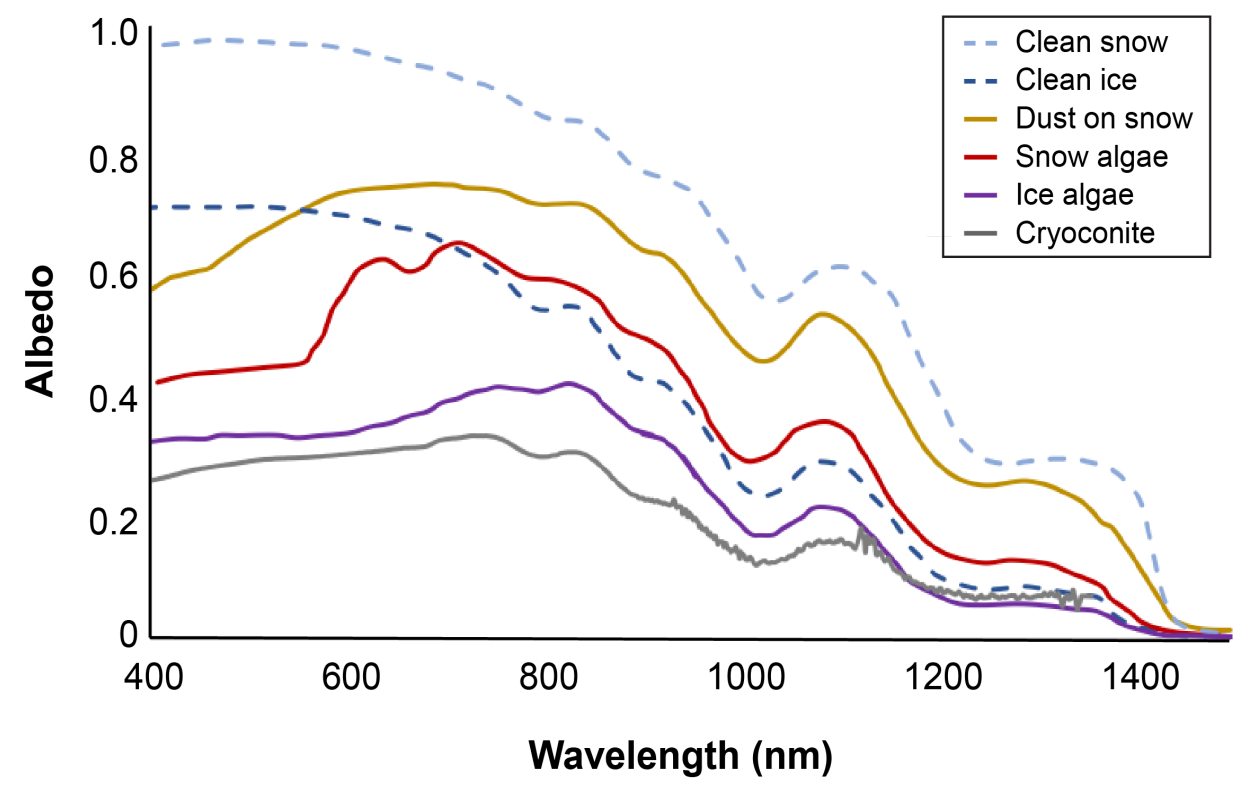

139 Figure 3. Example spectral albedo profiles $(400-1500 \mathrm{~nm})$ for snow and ice with a variety of common 140 cryosphere contaminants. Change in spectral shape is a useful indicator of the dominant absorber at the 141 surface. For example, the characteristic $680 \mathrm{~nm}$ chlorophyll absorption feature visible in the snow algae 142 spectra clearly differentiates it as biotic relative to abiotic dust. It also indicates snow conditions, where 143 lower near infrared albedo indicates larger grained (older) snow and ice. Cold, dry snow is not habitable 144 to algae, so both visible and near infrared albedo are lower when algae are present. Although these are 145 single characteristic curves, intended as a demonstration of the variability of snow and ice albedo with 146 abiotic and biotic darkening, the absolute magnitude of change depends on the concentration and distribution of particles across the surface as well as the age of the snow and ice surfaces. Spectra re-

Known drivers of BAR:

151 Albedo change is a key parameter affecting glacier melt (Box et al., 2012) with various 152 impurities_-both biotic and abiotic_-affecting albedo across wavelengths (Fig. 3).

153 With glacial ice covering $\sim 10 \%$ of Earth's surface and permanent and seasonal snow covering 154 up to $35 \%$ (Hell et al., 2013), clear potential exists for snow and ice algae to alter global albedo 155 (Lutz et al., 2016b; Segawa et al., 2018). Because the basic natural history, ecology, and 156 physiology of snow and ice algae have been recently reviewed (Hoham and Remias, 2020; 157 Williamson et al., 2019), here we summarize only key details in the context of BAR. We do the 
same for the other known BAR contributor, cryoconite, which has also been reviewed elsewhere

159 (Cook et al., 2016).

\section{Snow and ice algae}

162 Before summarizing the role of algae in BAR, we need to again consider terminology. The term 163 glacier algae has been proposed (e.g., Williamson et al., 2019) to differentiate algae living on

164 terrestrial ice from algae living on sea ice (Boetius et al., 2015) and algae living on snow

165 (Hoham and Remias, 2020). Glacier algae, however, has also been used as a collective term to 166 refer to all algae living in glacier environments (i.e., ice and snow algae, Dial et al., 2018). Thus, 167 a lack of clarity exists about whether "glacier algae" refers to all algae in a glacier environment 168 or more specifically, to only algae living on glacial ice. This distinction is important because in 169 the terrestrial realm, algae occupy both snow and ice, with overlapping distributions, yet each 170 habitat selects for distinct taxa: mainly Chlorophyceae on snow, particularly the "red" or 171 "watermelon snow" producing genera Chlamydomonas, Chloromonas and Sanguina 172 (Procházková et al., 2019; Remias et al., 2013, 2005), and Zygnematophyceae on ice (Remias 173 et al., 2012, 2009). Snow and ice algae on glaciers also vary in their life-histories, surfacing 174 strategies following winter snow accumulation, and pigmentation biochemistry (Hoham and 175 Remias, 2020; Williamson et al., 2019). We consider it more useful to reserve glacier algae as a 176 collective term for all algae living in glacier ecosystems, thereby differentiating these algae from 177 those living on sea ice. In line with this recommendation, we can then use more specific terms 178 to further delineate glacier algae into its two components-"snow algae" for algae living in snow 179 (Chlorophyta) and "ice algae" for algae living in ice (Streptophyta). When needed for added 180 clarity, "glacier" can precede either term (e.g., glacier ice algae versus sea ice algae).

182 Snow and ice algae pigments vary in color and reduce albedo by as much as $48 \%$ and $56 \%$, 183 respectively, when compared to a 'clean' surface (Table 1). Red snow algae produce 
184 astaxanthin (Remias et al., 2005), an intracellular carotenoid that colors their cells, and the 185 snow they inhabit, red. Astaxanthin likely protects the algae's photosynthetic apparatus from 186 damage under high UV conditions (Remias et al., 2005). Ice algae produce the phenol 187 purpurogallin, a pigment that imparts purple-gray coloring to their cells and surrounding ice 188 surfaces (Remias et al., 2011). For both snow and ice algae, the absorption spectra of their red 189 and purple carotenoids (astaxanthin and purpurogallin, respectively) are correlated with the 190 largest increase in melt (Dial et al., 2018). Seasonal timing and geographic location likely control 191 algal cell number due to the availability of liquid water and nutrients, as evidenced by a positive 192 correlation between algal abundance and debris (Stibal et al., 2015), an increase in algal 193 abundance near snow-ice transitions where liquid water is more abundant (Takeuchi et al., 194 2006), and decreasing algal biomass with increasing altitude (Takeuchi and Kohshima, 2004;

195 Tanaka et al., 2016; Yoshimura et al., 1997). Increases in snow and ice algae abundance have 196 been experimentally linked to accelerated melt (Dial et al., 2018; Ganey et al., 2017) (see Box 197 1). For ice algae, each doubling of the population has been linked to a $\sim 4 \%$ decline in albedo 198 (Stibal et al., 2017). 


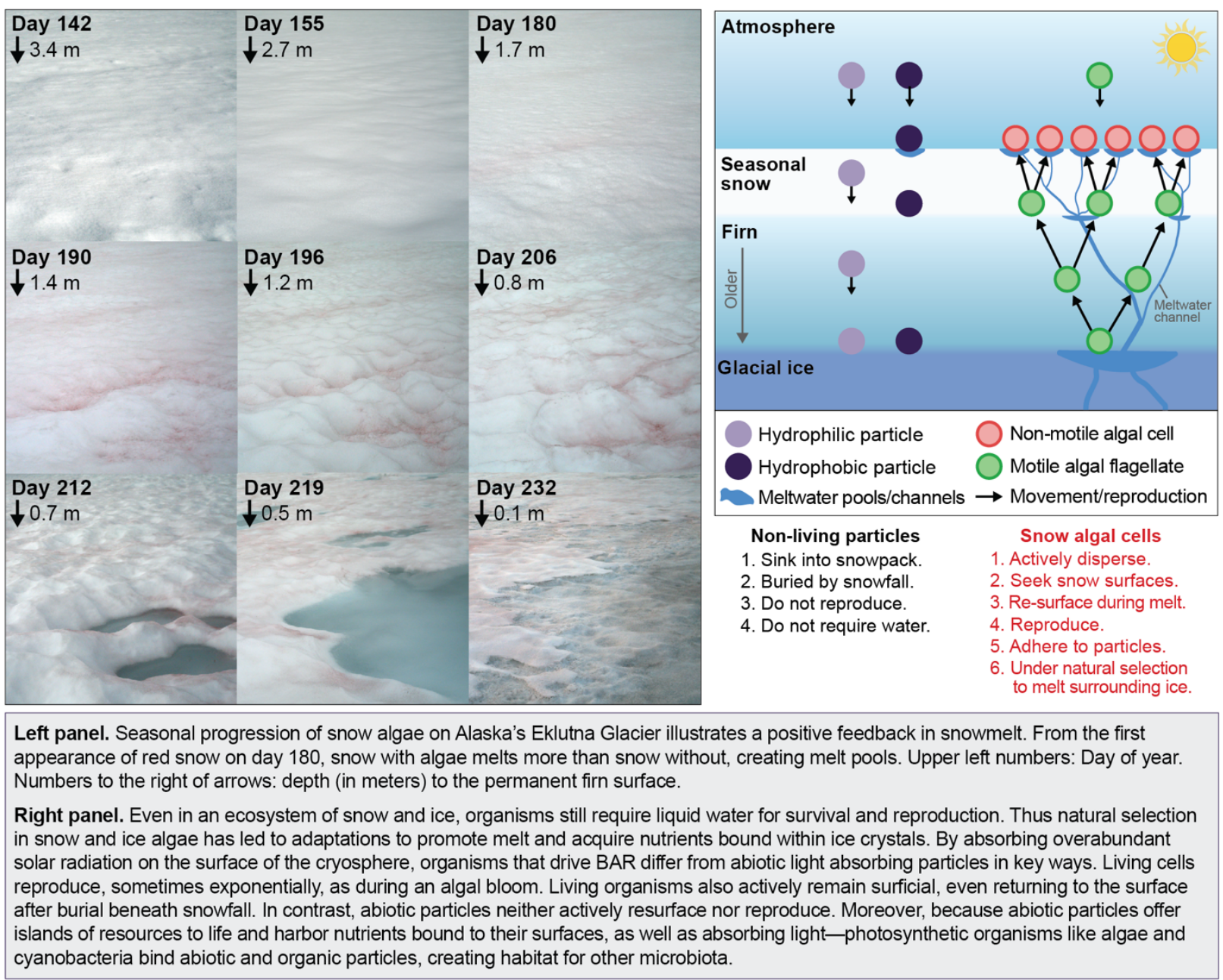
cyanobacteria bind abiotic and organic particles, creating habitat for other microbiota.

Box 1. Snow algae progression, movement, and comparison to non-living (abiotic) particles that reduce albedo. Photo credits: (c) G.Q. Ganey.

Algal abundance and its BAR changes during the melt season due to growth and 
211 algae increased from none in spring to $4.9 \times 10^{4}$ cells $\mathrm{mL}^{-1}$ in August (Onuma et al., 2020).

212 When liquid water and sunlight are no longer available due to new snow deposition, snow algae

213 transition to dormant cysts that germinate the following spring (Remias, 2012). If snowpack is

214 thin (e.g., on ice sheets) or melts quickly, ice algae persist for more of the melt season than

215 snow algae. Ice algae pigment (purpurogallin) also absorbs across a broad range of

216 wavelengths including UV and visible light, likely resulting in greater instantaneous albedo

217 reduction versus snow algae (Remias et al., 2012, 2011, 2009). Thus, while both snow and ice

218 algae decrease albedo, the net BAR impact of ice algae likely outweighs snow algae.

220 Pigment production in snow and ice algae may be under natural selection to convert solar

221 radiation to heat (Dial et al., 2018). Heat gain through absorption of visible light allows algae to

222 access nutrients bound within ice crystals while also producing meltwater for growth and

223 reproduction. On the Greenland ice sheet, ice algae direct up to $65 \%$ of incident energy to

224 surface melting compared to $\sim 2.5 \%$ or less to photochemistry (Williamson et al., 2020). Thus,

225 natural selection appears to favor albedo-reducing pigmentation that strikes a balance between

226 melt-inducing coloration and all-absorbing black that would overheat cells and disrupt their

227 function (Dial et al., 2018). Because snow and ice algae generate liquid from frozen water, a

228 positive feedback loop between them and the ice features they inhabit may be critical to

229 cryosphere decline (Anesio et al., 2017; Ganey et al., 2017; Hotaling et al., 2017b; Khan et al.,

230 2020; Stibal et al., 2012; Takeuchi, 2009). However, snow and ice algae contribution to BAR is

231 highly variable. For instance, snow algae abundance was negatively correlated with snow

232 albedo on California snowfields but algal blooms did not meaningfully decrease albedo at the

233 snowfield-scale due to its concentration in localized patches (Thomas and Duval, 1995).

234 Conversely, across the southwestern Greenland ice Sheet, ice algae may account for up to $75 \%$

235 of albedo variability (Williamson et al., 2020). 
237 Table 1. An overview of biological albedo reduction (BAR) studies in the terrestrial cryosphere including

238 region, methodology, habitat or organism with albedo values (if reported), and measured impact. While

239 most studies focus on habitats that host organisms known to contribute to BAR, the measured albedo

240 reduction or melt generation may include the effects of abiotic factors. Disentangling the effects of biotic

241 and abiotic factors in albedo reduction remains a major challenge for the field.

\begin{tabular}{|c|c|c|c|c|}
\hline Region & Methodology & $\begin{array}{l}\text { Habitat/organism: Mean } \\
\text { albedo values ( } \pm \text { SD } \\
\text { where available) }\end{array}$ & $\begin{array}{l}\text { Measured impact: } \\
\text { Albedo reduction } \\
\text { or melt generation }\end{array}$ & Study \\
\hline Antarctica & $\begin{array}{l}\text { Ground-based surface } \\
\text { albedo (Analytical Spectral } \\
\text { Devices FieldSpec® } 4 \\
\text { hyperspectral } \\
\text { spectroradiometer, spectral } \\
\text { range: } 350-2500 \mathrm{~nm} \text { ) }\end{array}$ & $\begin{array}{l}\text { Clean snow: } 0.85 \pm 0.043 \\
\text { Red snow: } 0.65 \pm 0.09 \\
\text { Green snow: } 0.44 \pm 0.12\end{array}$ & $\begin{array}{l}\text { Mean albedo } \\
\text { reduction from clean } \\
\text { snow to: } \\
\text { Red snow: } \sim 24 \% \\
\text { Green snow: } \sim 48 \%\end{array}$ & Khan et al., 2020 \\
\hline $\begin{array}{l}\text { Arctic } \\
\text { (Svalbard, } \\
\text { Northern } \\
\text { Sweden, } \\
\text { Greenland, } \\
\text { Iceland) }\end{array}$ & $\begin{array}{l}\text { Ground-based surface } \\
\text { albedo (SolarLight, } \\
\text { PMA2100 radiometer, } \\
\text { spectral range: } 400-700 \\
\mathrm{~nm} \text { ) }\end{array}$ & $\begin{array}{l}\text { Clean snow: } 0.90 \pm 0.05 \\
\text { Red snow: } 0.50-0.75\end{array}$ & $\begin{array}{l}\text { Between } \sim 17 \text { and } \\
44 \% \text { reduction from } \\
\text { clean snow to red } \\
\text { snow } \\
\sim 13 \% \text { reduction } \\
\text { over one melt } \\
\text { season }\end{array}$ & Lutz et al., 2016b \\
\hline Alaska, USA & $\begin{array}{l}\text { Ground-based surface } \\
\text { albedo (Analytical Spectral } \\
\text { Devices, FieldSpec® Pro } \\
\text { VNIR spectrometer, } \\
\text { spectral range: } 350-1050 \\
\text { nm.) }\end{array}$ & $\begin{array}{l}\text { Clean bare ice (cryoconite } \\
<5 \mathrm{~g} \mathrm{~m}^{-2} \text { ): } 0.45 \pm 0.07 \\
\text { Cryoconite-bearing ice: } \\
0.32 \pm 0.21\end{array}$ & $\begin{array}{l}\text { Mean albedo } \\
\text { reduction from clean } \\
\text { bare ice to } \\
\text { cryoconite-bearing } \\
\text { ice: } \sim 29 \% \text { reduction }\end{array}$ & Takeuchi 2009 \\
\hline Alaska, USA & $\begin{array}{l}\text { Ground-based surface } \\
\text { albedo (cable suspended } \\
\text { pyrometer; Kipp and Zonen } \\
\text { Model } 6 \mathrm{~B}, \text { spectral range: } \\
0.3-2.8 \mathrm{~mm} \text { ) }\end{array}$ & $\begin{array}{l}\text { Snow-buried shrubs: } 0.85 \\
\text { Exposed shrubs: } 0.60\end{array}$ & $\begin{array}{l}\text { Transition from } \\
\text { shrub-free tundra to } \\
\text { shrubland could } \\
\text { produce a } 69 \text { to } \\
75 \% \text { increase in } \\
\text { absorbed solar } \\
\text { radiation during the } \\
\text { snow-cover period }\end{array}$ & Sturm 2005 \\
\hline California, USA & $\begin{array}{l}\text { Ground-based surface } \\
\text { albedo (broad band LiCor } \\
\text { quantum sensor (Model: } \\
\text { "Quantum", spectral range: } \\
400-700 \mathrm{~nm} \text { ) }\end{array}$ & $\begin{array}{l}\text { Clean snow: } 0.58 \pm 0.08 \\
\text { Red snow: } 0.46 \pm 0.11\end{array}$ & $\begin{array}{l}\text { Mean reduction of } \\
\sim 21 \% \text { from clean to } \\
\text { red snow }\end{array}$ & $\begin{array}{l}\text { Thomas and } \\
\text { Duval } 1995\end{array}$ \\
\hline
\end{tabular}




\begin{tabular}{|c|c|c|c|c|}
\hline European Alps & $\begin{array}{l}\text { Ground-based surface } \\
\text { albedo (Hand Held } \\
\text { Analytical Spectral Devices } \\
\text { Field Spectrometer, } \\
\text { spectral range: } 325- \\
1075 \mathrm{~nm} \text { ) }\end{array}$ & $\begin{array}{l}\text { Ice algae: } 0.13-0.46 \text { at } \\
680 \mathrm{~nm}\end{array}$ & $\begin{array}{l}\text { Up to } 72 \% \text { reduction } \\
\text { in reflectance at } 680 \\
n m^{*} \text { for ice hosting } \\
\text { between } 0.2 \times 10^{5} \\
\text { to } 2.9 \times 10^{5} \text { cells } / \mathrm{mL}\end{array}$ & $\begin{array}{l}\text { Di Mauro et al., } \\
2020\end{array}$ \\
\hline $\begin{array}{l}\text { Greenland } \\
\text { (outlet glacier) }\end{array}$ & $\begin{array}{l}\text { Ground-based surface } \\
\text { albedo SolarLight, } \\
\text { PMA2100 radiometer, } \\
\text { spectral range: } 400-700 \\
\mathrm{~nm})\end{array}$ & $\begin{array}{l}\text { Clean snow: } 0.75 \pm 0.05 \\
\text { Red snow: } 0.49 \pm 0.08 \\
\text { Green snow: } 0.44 \pm 0.04 \\
\text { Clean ice: } 0.58 \pm 0.08 \\
\text { Gray ice: } 0.35 \pm 0.01 \\
\text { Cryoconite holes: } 0.23 \pm \\
0.15\end{array}$ & $\begin{array}{l}\text { Mean reduction } \\
\text { from clean snow to: } \\
\text { Red snow: } \sim 35 \% \\
\text { Green snow: } \sim 41 \% \\
\text { Mean reduction } \\
\text { from clean ice to: } \\
\text { Gray ice: } \sim 40 \% \\
\text { Cryoconite holes: } \\
\sim 60 \%\end{array}$ & Lutz et al., 2014 \\
\hline $\begin{array}{l}\text { Greenland Ice } \\
\text { Sheet }\end{array}$ & $\begin{array}{l}\text { Ground-based surface } \\
\text { albedo (two opposed } \\
\text { Apogee SP-110 } \\
\text { pyranometers, spectral } \\
\text { range: } 300-1100 \mathrm{~nm} \text { ) }\end{array}$ & $\begin{array}{l}\text { Clean ice: } 0.59 \pm 0.01 \\
\text { Cryoconite: } 0.35 \pm 0.01 \\
\text { Gray ice: } 0.26 \pm 0.01\end{array}$ & $\begin{array}{l}\text { Mean reduction } \\
\text { from clean ice to: } \\
\text { Cryoconite: } \sim 41 \% \\
\text { Gray ice: } \sim 56 \%\end{array}$ & Yallop et al., 2012 \\
\hline $\begin{array}{l}\text { Greenland Ice } \\
\text { Sheet }\end{array}$ & $\begin{array}{l}\text { Laboratory-based nutrient } \\
\text { additions, surface } \\
\text { reflectivity }\end{array}$ & $\begin{array}{l}\text { Early stage cryoconite: } \\
0.31 \\
\text { After carbon accumulation: } \\
0.16\end{array}$ & $\sim 48 \%$ reduction & $\begin{array}{l}\text { Musilova et al., } \\
2016\end{array}$ \\
\hline $\begin{array}{l}\text { Greenland Ice } \\
\text { Sheet }\end{array}$ & $\begin{array}{l}\text { Ground-based surface } \\
\text { albedo (Analytical Spectral } \\
\text { Devices, FieldSpec® } 2 \text { with } \\
\text { hemispheric cosine } \\
\text { receptor, spectral range: } \\
350-2500 \mathrm{~nm} \text { ) }\end{array}$ & $\begin{array}{l}\text { Ice surface after winter } \\
\text { snowpack ablation: } \\
\text { decrease from } 0.50 \text { to } 0.42 \\
\text { in } 35 \text { days }\end{array}$ & $\begin{array}{l}\sim 3.8 \% \text { albedo } \\
\text { reduction per algal } \\
\text { population doubling }\end{array}$ & Stibal et al., 2012 \\
\hline $\begin{array}{l}\text { Greenland Ice } \\
\text { Sheet }\end{array}$ & $\begin{array}{l}\text { Field spectroscopy } \\
\text { (Analytical Spectral } \\
\text { Devices, FieldSpec® Pro } 3 \\
\text { spectroradiometer with } \\
\text { ASD cosine collector, } \\
\text { spectral range: } 350-2500 \\
\text { nm), radiative transfer } \\
\text { model, UAV, satellite } \\
\text { remote sensing, runoff } \\
\text { modelling }\end{array}$ & Ice algae & $\begin{array}{l}\text { Additional } 8.8-12.2 \\
\text { Gt of runoff from the } \\
\text { western Greenland } \\
\text { ice sheet in } 2016 \text { ( } 9 \text { - } \\
13 \% \text { of total runoff) }\end{array}$ & Cook et al., 2020b \\
\hline $\begin{array}{l}\text { Greenland Ice } \\
\text { Sheet }\end{array}$ & $\begin{array}{l}\text { Field incubations, } \\
\text { quantification of } \\
\text { phytophysiological } \\
\text { mechanisms }\end{array}$ & Ice algae & $\begin{array}{l}\sim 1.86 \mathrm{~cm} \text { water } \\
\text { equivalent surface } \\
\text { melt per day in } \\
\text { patches of high } \\
\text { algal abundance }\end{array}$ & $\begin{array}{l}\text { Williamson et al., } \\
2020\end{array}$ \\
\hline
\end{tabular}




\begin{tabular}{|c|c|c|c|c|}
\hline Himalaya & $\begin{array}{l}\text { Ground-based surface } \\
\text { albedo (Pyranometers) }\end{array}$ & Cryoconite: 0.09 & $\sim 30 \%$ reduction & $\begin{array}{l}\text { Takeuchi et al., } \\
2000\end{array}$ \\
\hline Iceland & $\begin{array}{l}\text { Ground-based surface } \\
\text { albedo (SolarLight, } \\
\text { PMA2100 radiometer, } \\
\text { spectral range: } 400-700 \\
\mathrm{~nm} \text { ) }\end{array}$ & $\begin{array}{l}\text { Clean snow: } 0.76 \pm 0.08 \\
\text { Red snow: } 0.56 \pm 0.14\end{array}$ & $\begin{array}{l}\text { Mean reduction } \\
\text { from clean to red } \\
\text { snow: } \sim 26 \%\end{array}$ & Lutz et al., 2015 \\
\hline
\end{tabular}

242 *Albedo reduction calculated from data in the manuscript.

244 Cryoconite

245 Cryoconite is a granular sediment found on the surface of glaciers that typically includes

246 biological material (Cook et al., 2016; Fountain et al., 2008). Cryoconite forms when sediment

247 particles accumulate on an icy surface and it provides a substrate for microbial growth (organic

248 phase; Figs. 1, 2E). The dark coloration of cryoconite stems from humic substances: residual,

249 highly polymerized compounds remaining after bacterial decomposition of organic matter

250 (Takeuchi, 2002). The most common primary producers associated with cryoconite are

251 filamentous cyanobacteria (Chrismas et al., 2018, 2015; Segawa et al., 2017) which fix N and

252 provide key nutrients to other cryoconite microbiota (Telling et al., 2012, 2011). Many

253 cyanobacteria also produce extracellular polymeric substances that serve as a key carbon (C)

254 source for heterotrophs (Stibal et al., 2012), a cryo- and/or UV-protectant (Tamaru et al., 2005),

255 and an adhesive_-binding particles together and facilitating biofilm formation. Cryoconite is a

256 particularly strong driver of BAR on low-latitude glaciers (e.g., in Central Asia; Takeuchi et al.,

257 2018). Indeed, on some glaciers, filamentous, cryoconite-associated cyanobacteria form

258 granular mats that cover the entire ice surface (Segawa and Takeuchi, 2010). Cryoconite

259 abundance can exceed $200 \mathrm{~g} / \mathrm{m}^{-2}$ in dry weight, accelerating the local melt by as much as $300 \%$

260 (Kohshima et al., 1992; Takeuchi et al., 2018).

262 When cryoconite is abundant, it can cluster and develop into cryoconite holes (Figs. 1, 2E) 263 depressions of varying depths and diameters - that are formed by the acute, localized albedo 
264 reduction of the cryoconite. Cryoconite holes are typically water-filled, sediment-rich, and are 265 host to diverse assemblages of microorganisms, fungi, viruses, and invertebrates (Anesio et al., 266 2007; Bellas et al., 2020, 2013; Cameron et al., 2012; Cook et al., 2016; Edwards et al., 2013, 267 2013; Hodson et al., 2010; Lutz et al., 2019; Segawa et al., 2017, 2017; Takeuchi et al., 2001b).

268 Organic matter accumulation (leading to cryoconite hole formation) can reduce surface 269 reflectivity from $\sim 16 \%$ to $\sim 31 \%$ (Musilova et al., 2016). When present, cryoconite and cryoconite 270 holes can be rare (covering less than $1 \%$ of the surface on the Greenland ice sheet, Ryan et al., 2712018 ) or common, covering as much 10\% of a glacier's ablation zone (Anesio et al., 2009, 272 2009; Anesio and Laybourn-Parry, 2012; Hodson et al., 2008, 2007). In contrast to dispersed 273 cryoconite, cryoconite holes likely have minimal effects on albedo as they are typically narrow 274 and vertical, and thus only receive direct radiation for short periods of time (Bøggild et al., 275 2010). However, warm weather can collapse cryoconite holes by melting the ice surface faster 276 than the solar-heated cryoconite can deepen the hole, thereby re-dispersing cryoconite onto the 277 ice surface where its BAR contribution increases (Takeuchi et al., 2018).

\section{Potential drivers of BAR:}

280 To date, the global study of BAR in the cryosphere has focused almost exclusively on the 281 effects of algae and cryoconite. A hyper focus on these drivers is reasonable given their global 282 distribution and the near certainty that they are the dominant forces driving BAR in snow and ice 283 ecosystems. However, the same ecosystems host many other organisms, from fungi and other 284 microeukaryotes to invertebrates (Hotaling et al., 2017a, 2017b; Kohshima, 1984; Perini et al., 285 2019), often in large numbers. For instance, the darkly pigmented glacier ice worm $(\sim 2 \mathrm{~cm}$ long, $2863 \mathrm{mg}$ wet weight) can reach densities of $10-10^{3} \mathrm{~m}^{-2}$ on North American glaciers (Fig. 2B;

287 Hotaling et al., 2019a; Mann et al., 1980; Shain et al., 2001). Dozens of vertebrates, including 288 humans, also use glaciers and perennial snow (Rosvold, 2015). Thus, non-algal biodiversity has 289 the potential to affect BAR directly through the presence of organisms and their byproducts 
290 (e.g., fecal waste, Fig. 2A) or indirectly via nutrient inputs and interactions among organisms. In

291 this section, we highlight the myriad of potential drivers of BAR on ice sheets, glaciers, and 292 snowfields.

\section{Surface microbes}

295 Snow and ice algae co-occur with heterotrophic communities of viruses, bacteria, fungi, and 296 other microeukaryotes (Anesio et al., 2009, 2007; Anesio and Laybourn-Parry, 2012; Hamilton 297 and Havig, 2017; Krug et al., 2020; Lutz et al., 2015; 2016a; Perini et al., 2019; Stibal et al., 298 2020). In terms of abundance, the photic zone of glaciers may contain $10^{21}-10^{26}$ cells of 299 bacteria and archaea (Irvine-Fynn et al., 2012; Irvine-Fynn and Edwards, 2014). Similar to 300 algae, other microbiota also synthesize pigments for photosynthesis, to protect from UV damage, or absorb radiant energy and regulate temperature, and thus their BAR effects should be considered. For instance, on King George Island, Antarctica, phototrophic cyanobacteria can account for $\sim 40 \%$ of the chlorophyll-a containing organisms (Tamaru et al., 2005). In addition,

304 Hymenobacter, a common bacterium in ice and snow, makes at least four carotenoids that absorb light in the $475-500 \mathrm{~nm}$ region (Dial et al., 2018). Common cold-adapted fungi also include melanized filamentous species (Cordero et al., 2018; Perini et al., 2019) that are

307 typically dark brown or black in color (Culka et al., 2017) and their contribution to BAR is likely 308 similar to the humic substances in cryoconite. Fungal biomass can reach $10^{4}-10^{5}$ colony 309 forming units per $100 \mathrm{ml}$ on snow and ice surfaces (de Menezes et al., 2019; Hamilton and 310 Havig, 2017), an abundance similar to the upper limit of $1.8 \times 10^{5}$ algal cells $\mathrm{mL}^{-1}$ observed on 311 the Greenland ice sheet (Perini et al., 2019).

313 The main contribution of non-algal surface microbiota to BAR, however, is likely through 314 interactions with algae via nutrient acquisition and cycling (Krug et al., 2020). Snow and ice 315 algae are water-limited and potentially nutrient-limited (Anesio et al., 2017; Ganey et al., 2017; 
316 Hamilton and Havig, 2017, 2020; Lutz et al., 2015; Takeuchi et al., 2006). Algae and other

317 psychrophilic microorganisms are also known to interact in their use of several limiting

318 resources [e.g., C, iron (Fe), and N (Anesio et al., 2017; Harrold et al., 2018; Havig and

319 Hamilton, 2019; Hodson et al., 2008; Phillips-Lander et al., 2020; Stibal et al., 2009; Telling et

320 al., 2012, 2011)]. Therefore, bacteria and fungi may increase ecosystem carrying capacity, and

321 thus the abundance of algae and algal BAR, through the liberation of phosphorus $(P)$ and $F e$

322 (and other micronutrients) from rock flour and surface debris, while producing labile organic $\mathrm{C}$

323 that is readily consumed by heterotrophs through photosynthesis (Kellerman et al., 2020;

324 Musilova et al., 2016). Experimental evidence supports this thesis; bacteria enhance the growth

325 rate and abundance of snow algae in the presence of Fe-bearing minerals (Harrold et al., 2018;

326 Lutz et al., 2015; Phillips-Lander et al., 2020). Viruses have not been directly linked to BAR but

327 they may play an indirect role by regulating bacterial mortality, thereby influencing levels of

328 dissolved organic matter (Anesio et al., 2007; Bellas et al., 2013). Thus, as in other ecosystems

329 (Weinbauer, 2004), viruses likely impact biogeochemical cycles in snow and ice, thereby

330 affecting the growth and abundance of organisms that propagate BAR (e.g., snow and ice 331 algae). 


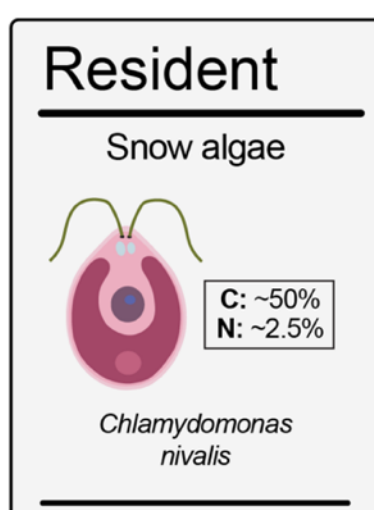

Total C: $\sim 1.7 \mathrm{~kg}$

Total N: $\sim 0.1 \mathrm{~kg}$

Ice worms

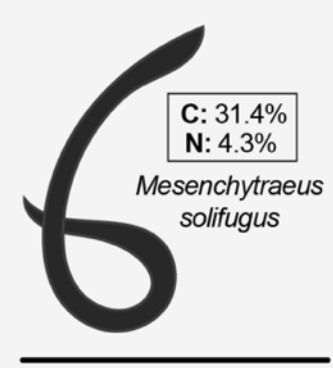

Total C: $\sim 9.7 \mathrm{~kg}$

Total N: $\sim 1.3 \mathrm{~kg}$

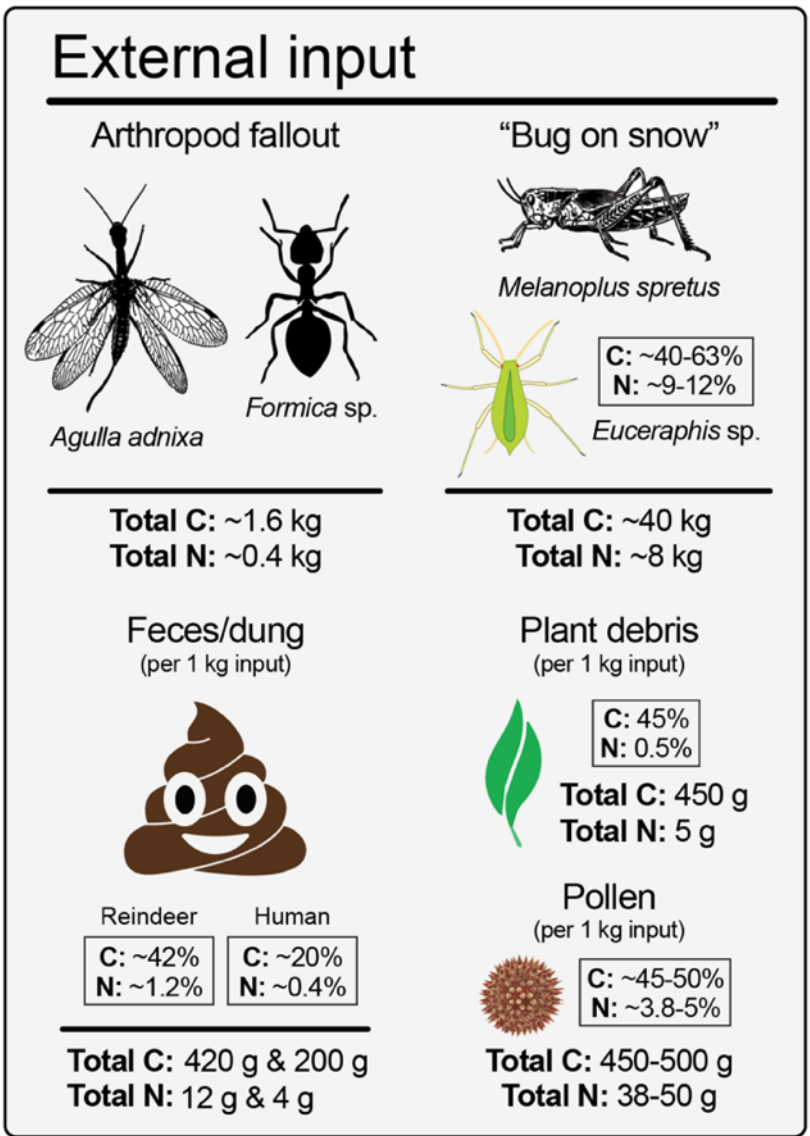

Total N: $12 \mathrm{~g} \& 4 \mathrm{~g}$
"Bug on snow"

Melanoplus spretus

C: 40-63\%

Euceraphis sp

Total C: $\sim 40 \mathrm{~kg}$

Total N: $\sim 8 \mathrm{~kg}$

Plant debris

N: $0.5 \%$

Total C: $450 \mathrm{~g}$

Total N: $5 \mathrm{~g}$

Pollen

er $1 \mathrm{~kg}$ input)

C: $~ 45-50 \%$

N: $~ 3.8-5 \%$

Total N: $38-50 \mathrm{~g}$

333 Figure 4. Contribution of biomass from resident and external sources to the nutrient composition of ice sheets, glaciers, and snowfields. Total carbon $(\mathrm{C})$ and nitrogen $(\mathrm{N})$ estimates are for a $0.1 \mathrm{~km}^{-2}$ area and are calculated from empirical observations of abundances and C:N ratios of representative biomass (except where noted as "per $1 \mathrm{~kg}$ input"). Since no empirical estimates exist for input of feces/dung, plant debris, and pollen to the cryosphere, these numbers are calculated on a per kg basis.

\section{Invertebrates}

340 A variety of invertebrates_ranging from microscopic rotifers to macroscopic ice worms-live in

341 glacier and snowfield ecosystems (Hotaling et al., 2019b; Shain et al., 2016; Zawierucha et al.,

342 2018) and even more are marooned there via atmospheric deposition as "arthropod fallout" (Fig.

343 4; Edwards, 1987). Arthropod fallout occurs on glaciers and snowfield globally (reviewed by

344 Edwards, 1987), likely on any ice or snow surface that is relatively close (perhaps less than 50

$345 \mathrm{~km}$ ) to ice-free habitat. Even portions of the Greenland ice sheet likely see some amount of

346 arthropod fallout as a diverse invertebrate community containing many winged species has 
been described just $2 \mathrm{~km}$ from its margin (Hansen et al., 2016). The presence of invertebrates on glaciers and snowfields raises three BAR-related hypotheses: (1) If sufficient invertebrate

349 densities are reached (with dark enough pigmentation), in situ communities or atmospheric 350 depositions may meaningfully lower albedo, driving "bug on snow" events (Fig. 4) that are akin 351 to well-known "dust on snow" events (Painter et al., 2007; Skiles et al., 2015; Zhang et al., 352 2018). (2) Macroinvertebrates may attract other organisms (e.g., birds) to glacial ecosystems, 353 whose activity reduces albedo. (3) Arthropod fallout meaningfully alters the nutrient dynamics of 354 the cryosphere, thereby affecting known BAR drivers (e.g., algal blooms).

Invertebrates on glaciers and snowfields were first recorded in the 1800s (von Humboldt, 1808),

357 and diverse, mostly arthropod communities have been described from cryosphere habitats 358 worldwide (Durbin, 1975; Edwards, 1987; Edwards and Banko, 1976; Kohshima, 1984; Mann et 359 al., 1980; Masutti and Covassi, 1978; Swan, 1963). Invertebrates delivered by wind to cold, 360 high-UV glacial ecosystems typically find the environment to be lethal (Edwards, 1987; Edwards 361 and Banko, 1976; Heinrich and Bell, 1995; Swan, 1963). However, resident metazoans in the 362 cryosphere do occur, including nematodes (Azzoni et al., 2015), rotifers (Shain et al., 2016), 363 tardigrades (Zawierucha and Shain, 2019), and glacier ice worms (Dial et al., 2012; Hotaling et 364 al., 2019a). Resident invertebrates are often present at high densities (hundreds to thousands 365 per $\mathrm{m}^{2}$ (Goodman, 1971; Mann et al., 1980) and tend to be highly melanized (see Fig. 1; Mani, 366 1968). Thus, like snow algae and other pigmented taxa, their presence on the surface alone 367 likely drives BAR.

369 However, not all invertebrates are present at the surface continuously (Fig. 2B). For instance, 370 on coastal glaciers of North America, a daily migration of heavily pigmented glacier ice worms

371 occurs during summer, with worms typically congregating at densities $>100 \mathrm{~m}^{-2}$ (wet mass $\sim 0.31$ $372 \mathrm{~g})$ on the snow surface 4-6 hours before sunset and retreating back into the ice before dawn 
373 (Fig. 2B; Goodman, 1971; Mann et al., 1980). Ice worms may also affect BAR indirectly by

374 exerting top-down control on algae abundance through grazing (and thus decreasing BAR),

375 adding bioavailable nutrients that stimulate algal growth through feeding, and by attracting

376 foragers (Hotaling et al., 2019b). Ice worms consume algae (Goodman, 1971; Murakami et al.,

377 2015) but it is currently unknown if their grazing substantially impacts algal abundance. Future

378 studies should compare algae abundance on glaciers with and without ice worms (e.g., in

379 southeast Alaska; Dial et al., 2012; Hartzell et al., 2005) to investigate this relationship. Another

380 dark-bodied invertebrate_-springtails (subclass Collembola)_are much smaller than ice worms

381 but can be present at densities $>5,000 \mathrm{~m}^{-2}$ during daylight (Mann et al., 1980). In terms of

382 nutrient mass, $\mathrm{C}$ and $\mathrm{N}$ content of ice worms is $31.4 \% \mathrm{C}$ and $4.3 \% \mathrm{~N}$ (Havig and Hamilton,

3832019 ) which would add $9.7 \mathrm{~kg}$ of $\mathrm{C}$ and $1.3 \mathrm{~kg}$ of $\mathrm{N}$ over a $0.1 \mathrm{~km}^{2}$ glacier assuming a

384 conservative density of 100 worms $\mathrm{m}^{-2}$ (Fig. 4). Springtail $\mathrm{C}$ and $\mathrm{N}$ content ranges from $15-47 \%$

385 and $5-14 \%$, respectively and individual springtails range in weight from $\sim 10$ to 100 s of $\mu \mathrm{g}$

386 (Fiera, 2014), thus their $\mathrm{C}$ and $\mathrm{N}$ contribution may be similar to ice worms.

While resident invertebrates actively move throughout the ice matrix, wind-blown invertebrates are mostly static and reduce albedo on extremely localized scales (Fig. 2C). However, largescale depositions, where one taxon is heavily deposited do occur and may induce "bug on

391 snow" events (see below, Fig. 4). During summer on an Alaskan snowfield (Edwards, 1987;

392 Edwards and Banko, 1976), biomass added via arthropod fallout was highest from mid-June to 393 early July and declined to nearly zero by early September. A similar temporal decline was 394 observed from July to August in the White Mountains, California, USA (Spalding, 1979). At its 395 peak, approximately $1.5 \mathrm{mg} \mathrm{m}^{-2}$ per day of dry invertebrate biomass was added. Although this is 396 low relative to dust events, which can deposit $\sim 100$ to $\sim 25,000 \mathrm{mg} \mathrm{m}^{-2}$ over 1-2 days, dust 397 events are episodic (Edwards and Banko, 1976) whereas arthropod fallout appears more 398 consistent. If we consider peak arthropod deposition to be from mid-June to early July and use a 
399 minimum area of $0.1 \mathrm{~km}^{-2}$, arthropod additions would add $3.2 \mathrm{~kg}$ of biomass to the system. For

400 comparison, snow algal biomass has been estimated at 1.2-3.3 kg over a similar area $\left(0.1 \mathrm{~km}^{-2}\right.$;

401 Painter et al., 2001; Takeuchi et al., 2006). Assuming a similar contribution to BAR, at these

402 deposition rates the contribution of arthropod biomass to albedo reduction could rise to the level

403 of algae. However, this estimate oversimplifies the concentrated nature of arthropod biomass

404 and does not account for the added melt-inducing physiology of algae.

405

406 "Bug on snow" events differ quantitatively and qualitatively from regular fallout. For instance, in

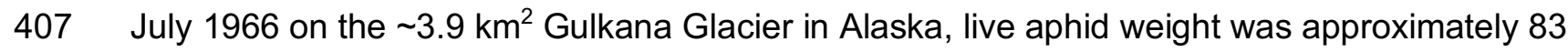

$408 \mathrm{~kg}$ after a major deposition (Edwards, 1987). In Montana, grasshoppers are entombed in at

409 least five glaciers, and tell the legacy of widespread, recurring depositions (Lockwood et al.,

410 1992, 1991). First reported as "billions of grasshopper carcasses" (Henderson, 1933),

411 grasshoppers were observed at densities up to $100 \mathrm{~m}^{-2}$ across a swath of the Rocky Mountains

412 and were so abundant that two glaciers within 25 km have been named "Grasshopper Glacier"

413 (Lockwood et al., 1992). Large-scale grasshopper deposits happened iteratively from 140-800

414 years ago (Lockwood et al., 1991, 1992, 1994) and were dominated by the now extinct Rocky

415 Mountain locust (Melanoplus spretus; Lockwood et al., 1991).

417 However, no measures of albedo reductions for single invertebrates, much less before and after

418 major "bug on snow" events, have been published and the global biogeography of "bug on

419 snow" events, including their spatial and temporal variability, remains unknown. This is likely

420 because the major foci of modern biological research on permanent ice have been in Greenland

421 and Antarctica, two isolated areas where arthropod deposition is rare or non-existent. Moreover,

422 documentation of real-time "bug on snow" events like the July 1966 observation in Alaska

423 require a unique combination of a skilled mountaineer with the biological expertise to record and

424 publish such an event. Looking ahead, however, there is reason to predict that the frequency of 
425 "bug on snow" events is in decline due to the extinction of species like M. spretus in North

426 America and contemporary global declines in insect diversity (Hallmann et al., 2017; Sanchez-

427 Bayo and Wyckhuys, 2019).

428

429 Arthropod biomass, particularly insect biomass, is typically of high quality and labile (i.e., with a 430 low C:N ratio; Yang and Gratton, 2014). Estimates of $\mathrm{C}$ and $\mathrm{N}$ in arthropod biomass range from $431 \sim 40-63 \%$ and 9-12\%, respectively (Havig and Hamilton, 2019; Hughes and Bazzaz, 2001; Small 432 et al., 2013). Thus, the $3.2 \mathrm{~kg}$ of arthropod biomass calculated above would add $\sim 1.6 \mathrm{~kg}$ of C 433 and $\sim 0.4 \mathrm{~kg}$ of $\mathrm{N}$ to the surface of a small $\left(0.1 \mathrm{~km}^{2}\right)$ glacier during peak deposition from mid434 June to early July (Fig. 4). For larger "bug on snow"” events, over $40 \mathrm{~kg}$ of $\mathrm{C}$ and $\sim 8 \mathrm{~kg}$ of $\mathrm{N}$ 435 could be added (Fig. 4). In contrast, ice and snow algae contribute a range of biomass values, 436 from $1.2 \mathrm{~kg} \mathrm{~km}^{-2}$ on ice sheets in Alaska (Takeuchi, 2013) to $33 \mathrm{~kg} \mathrm{~km}^{-2}$ in California (Painter et 437 al., 2001). Assuming the same $0.1 \mathrm{~km}^{-2}$ glacier area and algal biomass that is $\sim 50 \% \mathrm{C}$ and $2.5 \%$ 438 N (Gray et al., 2020; Hamilton and Havig, 2017; Havig and Hamilton, 2019; Spijkerman et al., 4392012 ), snow and ice algae would contribute $\sim 1.7 \mathrm{~kg}$ of $\mathrm{C}$ and $\sim 0.1 \mathrm{~kg}$ of $\mathrm{N}$. These comparisons 440 suggest arthropod biomass can substantially influence biogeochemical cycles on snow and ice 441 surfaces but presumably, surface primary productivity would provide more readily available C.

443 While studies are needed to characterize the bioavailability of nutrients, particularly $\mathrm{C}$ and $\mathrm{N}$, in 444 arthropod biomass and subsequent effects on snow and ice microbiota, the deposition of 445 invertebrates may impact BAR in another indirect way. Invertebrates on glaciers are a key 446 resource for other organisms, including invertebrates (Mann et al., 1980) and birds (Edwards 447 and Banko, 1976; Hotaling et al., 2019a; Vera et al., 2012). By attracting larger organisms to the 448 cryosphere, invertebrates likely increase the net biological activity of the cryosphere. And, by 449 also attracting their waste products (e.g., bird feces), invertebrates may influence BAR. In this 450 context, the potential for BAR hinges on two factors. First, that larger organisms like birds are 
451 being attracted from outside the cryosphere to feed on invertebrates. This is certainly true in the

452 case of ice worms in North America as none of their vertebrate predators nest directly on

453 glaciers and snowfields (Hotaling et al., 2019a). Second, that the net effect of increasing

454 biological activity on the cryosphere surface_-primarily through fecal and related inputs-

455 outweighs the removal of a local contaminant (the invertebrate) and its nutrients.

\section{$457 \quad$ Vertebrates}

458 Many mammals and birds, ranging from songbirds to ungulates and felids transiently use

459 glaciers and snowfields (Rosvold, 2015) for relief from abiotic or biotic factors (Hagemoen and

460 Reimers, 2002), foraging (Stevens, 1979), nesting (Hardy and Hardy, 2008; Hardy et al., 2018),

461 recreation (Reckin, 2013), and travel (Koshkarev, 1984). For BAR, the key aspect of vertebrates

462 on glaciers and snowfields are their inputs, whether feces, blood and other byproducts of

463 predation, or their own hair and feathers (Fig. 2A). For example, $60 \%$ of algal blooms along the

464 Antarctic Peninsula are within $5 \mathrm{~km}$ of penguin colonies and blooms are larger near bird or seal

465 colonies (Gray et al., 2020).

466

467 Worldwide, birds are the most diverse vertebrate group on glaciers and snowfields and are 468 therefore likely the vertebrate group that contributes the most to BAR. Birds forage on glaciers 469 and snowfields (Antor, 1995; Hardy et al., 2018; Hotaling et al., 2019a; Resano-Mayor et al., 470 2019) with latitudinal variation in their rates (higher foraging rates at lower latitudes; Edwards 471 and Banko, 1976; Verbeek, 1970). For BAR, birds may control arthropod abundance on glacier

472 and snowfield surfaces, effectively limiting biomass accumulation through time. At high-

473 latitudes, coastal glaciers and snowfields are heavily used by seabirds (and seals) and algal

474 blooms have been linked to penguin colonies (Remias et al., 2013), predatory bird prey (Fujii et 475 al., 2009), and seal carcasses (Ishikawa et al., 1986). In mountain ecosystems, birds play a role 476 in dispersal of glacier biota, as implicated in the genetic biogeography of ice worms (Dial et al., 
477 2012; Hotaling et al., 2019a). Some birds even nest on glaciers (Hardy and Hardy, 2008),

478 thereby attracting mammalian predators and increasing opportunities for fecal input. Larger

479 organisms can also be major sources of feces to glaciers and snowfields (Figs. 2A, 4).

480 Ungulates, particularly reindeer, migrate to snow- or ice-covered land daily in the summer as a 481 reprieve from heat and to escape flies (Rosvold, 2015). In Norway, $\sim 1,200$ reindeer have been 482 observed spending hours on snow (Hagemoen and Reimers, 2002) and their dung stains 483 snowfields over large areas (Rosvold, 2015). Brown bears and snow leopards also travel on ice 484 or snow (French et al., 1994; Koshkarev, 1984) but not in herds and thus likely have little to no 485 impact on BAR.

487 Vertebrate "input" (feces, feathers, blood) altering snowfield albedo in maritime environments is 488 well-known (Fujii et al., 2009) and similar effects likely occur on inland glaciers and snowfields. 489 For instance, fecal staining by emperor penguin colonies can be detected with satellite imagery 490 (Fretwell and Trathan, 2009). While the albedo of animal products remain to be quantified, it is 491 reasonable to assume they are similar to bare ground ( $\sim 15 \%$ reflectance), and thus much lower 492 than the $\sim 90 \%$ reflectance of fresh snow (Skiles et al., 2018). Humans, possibly the most 493 widespread vertebrate on glaciers and snowfields worldwide, also contribute to BAR. For 494 example, $\sim 1,000$ people attempt the most popular mountaineering route on Denali, the tallest 495 peak in North America, each year (Denali National Park and Preserve, 2019). In addition to 496 footprints altering the physical snow surface (Fig. 2A), climbers generate $\sim 2$ metric tons of fecal 497 waste on this single route, and the bulk of it is typically disposed of in crevasses (Goodwin et al., 498 2012; Pickering and Barros, 2015). While these feces may flow through the glacier and be 499 exported to lower elevations, fecal contamination of snow near camps and climbing routes has 500 been observed (Goodwin et al., 2012; McLaughlin et al., 2005) highlighting that camps, and 501 their methods for waste disposal, can still impact BAR at higher elevations. 
503 Nutrient inputs by vertebrates to cryosphere habitats may be substantial, particularly in high-use

504 areas (e.g., near a popular mountaineering route or large herd of reindeer). For instance,

505 reindeer feces contain $420 \mathrm{mg} \mathrm{C} / \mathrm{g}$ and $12 \mathrm{mg} \mathrm{N} / \mathrm{g}$ (dry mass; Hayashi et al., 2014). While

506 nutrient content of human fecal waste can vary with diet, as an example, solid waste from

507 Kolkata, India contained $200 \mathrm{mg} \mathrm{C} / \mathrm{g}$ and $3.7 \mathrm{mg} \mathrm{N} / \mathrm{g}$ (Pramanik et al., 2007). Assuming $1 \mathrm{~kg}$ of

508 fecal deposition on a $0.1 \mathrm{~km}^{2}$ glacier, reindeer feces add $420 \mathrm{~g}$ of carbon and $12 \mathrm{~g}$ of nitrogen

509 while human feces adds $200 \mathrm{~g}$ of $\mathrm{C}$ and $3.7 \mathrm{~g}$ of N (Fig. 4). Bird fecal deposition may provide a

510 uniquely important source of bioavailable N. For instance, seabird guano is used in high $\mathrm{N}$

511 fertilizer and can be $\sim 11 \% \mathrm{~N}$ of which only $0.8 \%$ is inorganic (mainly $\mathrm{NH}_{4}-\mathrm{N}$; Hartz and

512 Johnstone, 2006).

513

514 Assuming the loss of permanent snow and ice does not drive a corresponding decline in

515 vertebrate population densities, the BAR effects of vertebrates on the cryosphere is likely to

516 increase as snow and ice area declines and use is concentrated in ever smaller areas.

517 Moreover, the full suite of glacier and snowfield usage by vertebrate is likely underreported as

518 the remains of moose, African wild dogs, leopards, snowshoe hare, wolves, and various rodents

519 have melted out of glaciers and snowfields from North America to Africa (Andrews et al., 2012;

520 Farnell et al., 2004; Guest and Leedal, 1954; Hare et al., 2012; Lee, 2012; Mizuno, 2005;

521 Thesiger, 1970). High-altitude discoveries of extinct megafauna (Madsen, 2000) also highlights

522 the potential for historical usage of alpine glaciers and snowfields, perhaps leaving a legacy of

523 organic debris in extant snowfields which, when exposed, will further BAR.

524

525 Plants

526 Plants and plant matter are common on ice sheets, glaciers, and snowfields. The most well-

527 known floral resident of glaciers are "glacier mice" (Fig. 1)—balls of moss that are not attached

528 to the ice surface and "move" across it on glaciers worldwide (Coulson and Midgley, 2012; 
529 Hotaling et al., 2020). Glacier mice are typically $\sim 8-10 \mathrm{~cm}$ in diameter and harbor invertebrate

530 communities (Coulson and Midgley, 2012). In central Africa, moss colonizes the termini of

531 disappearing glaciers in the Rwenzori Mountains, Uganda (Uetake et al., 2014). Unlike glacier

532 mice, African moss aggregations are not formed by moss shoots but rather by dense

533 aggregations of gemmae (Fig. 1). On average, moss aggregates are $\sim 19 \mathrm{x} \sim 13 \mathrm{~mm}$ with a

534 broad distribution up to $46 \times 32 \mathrm{~mm}$. The aggregations experience daily freeze-thaw cycles, with

535 internal temperatures reaching $10^{\circ} \mathrm{C}$, and penetrate several millimeters into the ice due to

536 radiative warming (Uetake et al., 2014).

538 Similar to arthropods, plant fallout also occurs and may alter BAR directly and indirectly. In the

539 western USA, vegetation on snow and ice surfaces includes pine needles, grass, and lupine,

540 and contain $\sim 45 \% \mathrm{C}$ and $\sim 0.5 \% \mathrm{~N}$ while mosses are $\sim 8 \% \mathrm{C}$ and $\sim 0.2 \% \mathrm{~N}$ (Havig and Hamilton,

541 2019). Over 5,000 pollen grains/L have been observed in arctic snow (Bourgeois et al., 2001)

542 and in southern Greenland, pollen deposition has been estimated at $\sim 0.7$ grains cm$^{-2}$ year $^{-1}$

543 (Bourgeois, 1990). Pollen $\mathrm{C}$ and $\mathrm{N}$ content ranges from $\sim 45-50 \% \mathrm{C}$ and $\sim 2-5 \% \mathrm{~N}$ (dry mass;

544 Filipiak, 2016). Assuming $1 \mathrm{~kg}$ of deposition on a $0.1 \mathrm{~km}^{2}$ glacier, plant debris add $\sim 450 \mathrm{~g}$ of C

545 and $5 \mathrm{~g}$ of $\mathrm{N}$, moss add $80 \mathrm{~g}$ of $\mathrm{C}$ and $2 \mathrm{~g}$ of $\mathrm{N}$, and pollen add $\sim 450-500 \mathrm{~g}$ of $\mathrm{C}$ and $\sim 38-50 \mathrm{~g}$ of

$546 \mathrm{~N}$ (Fig. 4). However, accumulation rates of plant debris, moss, and pollen on most glaciers and

547 snowfields are largely unknown and likely vary by location and season.

\section{$549 \quad$ Biological shading}

550 While many biological factors may contribute to BAR and further melt, some might instead 551 shade the surface, thereby insulating it and preventing melt. This biological shading is similar552 albeit on a much smaller scale - to how rock glaciers and related landforms maintain ice through 553 debris cover (Jones et al., 2019). For example, the "movement" of glacier mice stems from 554 biological shading as the moss conglomerations protect the ice below from solar radiation and 
555 warm ambient temperatures while surrounding ice melts away. Eventually, this creates a

556 pedestal that the glacier mouse rests upon before tumbling off and restarting the process

557 (Hotaling et al., 2020). Similarly, reindeer fecal deposits can be deep enough that they transition

558 from driving melt through reduced albedo to actively insulating snow and ice. In Norway, depths

559 of fecal masses have been observed up to $\sim 30 \mathrm{~cm}$, well beyond the amount needed to protect

560 ice (Rosvold, 2015). Although likely negligible on large spatial scales except in rare, short-term

561 cases (e.g., tents in human mountaineering camps), larger-bodied animals on snow and ice

562 surfaces (particularly birds and mammals) may also cause local, transient shading.

563

\section{Climate change and anthropogenic effects}

565 Climate change is predicted to raise temperatures (Hansen et al., 2010), alter patterns of wind 566 and solar radiation (Hofer et al., 2017; Sydeman et al., 2014), increase meltwater run off (Huss 567 and Hock, 2018), and influence the population dynamics of biota around the world (Cavicchioli 568 et al., 2019; Parmesan, 2006). Thus, potential exists for climate change to enhance BAR.

569 However, the alternative—climate change mitigating BAR—perhaps through increased rainfall 570 washing away more biological particles should also be considered. Below, we consider both 571 perspectives, primarily in the context of the most pressing question for BAR: how will climate 572 change alter the timing, scale, and duration of snow and ice algae blooms?

574 Temperature and precipitation

575 Climate change has resulted in decreased snowfall versus rain in many locations and, in 576 general, this trend is expected to continue with increasing temperature (Diffenbaugh et al., 577 2013; Knowles et al., 2006; Krasting et al., 2013; Thackeray et al., 2019). However, changes will 578 not be uniform with snow amounts actually increasing in some areas (e.g., The Alaska Range, 579 Winski et al., 2017). At present, the strongest correlation between air temperature and snow 580 cover extent occurs between April and June in the northern hemisphere. Extended melt 
seasons due to rising temperatures should increase microbial growth by adding meltwater

582 earlier in the season (and likely at higher quantities throughout). In field experiments, the

583 addition of $250-\mathrm{mL}$ of water to a $2 \mathrm{~m}^{2}$ increased snow algal cell counts by $50 \%$ (Ganey et al.,

584 2017). And, due to added water and more algae in plots treated with excess water, bare ice was

585 exposed earlier in the melt season (Ganey et al., 2017). However, rainfall may limit the growth

586 of ice algal blooms by flushing algal cells from the ice surface or redistributing algal cells

587 elsewhere (Stibal et al., 2017). A positive correlation $\left(R^{2}=0.51, p<0.01\right)$ between darkening of

588 ice during summer and the timing of snow clearance from ice surfaces has been observed with

589 earlier snow clearance in spring leading to darker ice in summer (Tedstone et al., 2017). If snow

590 algae are "annuals" dispersing to snowfields each year from elsewhere (Onuma et al., 2018),

591 then snow depth may have no impact on their abundance and distribution. If, however, they are

592 "perennials" as current evidence suggests (Box 1; Hoham and Remias, 2020), then altered

593 snow depth may alter their distribution and abundance. If snow depths increase, snow algae

594 may fail to germinate due to a lack of meltwater reaching dormant cysts. If snow depths

595 decrease, germination will occur increasingly earlier until there is insufficient habitat available for 596 their growth and reproduction.

$598 \quad$ Nutrient change

599 Greater availability of resources (e.g., liquid water) may underlie the trophically expanded food 600 webs observed on some glaciers around the world. For instance, in addition to a standard 601 microbial assemblage, the Paradise Glacier on Mt. Rainier, USA, also supports ice worm 602 macro-consumers which are preyed upon by birds (Hotaling et al., 2019b). Though it is unclear 603 if more trophic levels on a glacier leads to an increase in BAR, a link seems plausible as it 604 would create more net biological activity on snow and ice surfaces. Thus, an increase in 605 nutrients—perhaps from expanded algal blooms, storm frequency, or wildfire (see below)— 
could lead to tropic expansions in the cryosphere. This potential is particularly clear given the

607 evidence that increased availability of key nutrients (e.g., C and N) can expand algal blooms.

609 Ongoing recession of glaciers may also increase local nutrient input. Glacier retreat contributes

610 fine dust particles to adjacent landscapes through bedrock grinding (Bullard et al., 2016) and

611 exposure of unconsolidated sediments may increase local addition of dust, typically rich in Fe

612 and $\mathrm{P}$, to nearby snow and ice. Added mineral dust will also increase mineral-microbe

613 aggregates that affect the surface architecture of snow and ice, provide opportunities for nutrient

614 biomining by microbial communities, and reduce albedo (leading to increased availability of

615 liquid water). For instance, ice algae in southwestern Greenland show a positive

616 photophysiological response to increased $\mathrm{P}$ availability, with $\mathrm{P}$ in this region likely sourced

617 locally from mineral dust (McCutcheon et al., 2021).

619 Global circulation models predict an increase in storms and other extreme weather events 620 (IPCC, 2019). In North America, the Arctic, and along the Antarctic Peninsula, cyclonic storms 621 deposit marine-derived aerosols containing $\mathrm{N}, \mathrm{P}$, potassium $(\mathrm{K})$, and Fe onto coastal glaciers 622 and icefields (Quinn et al., 2015). If storms increase in frequency, duration, or magnitude, then 623 cryospheric ecosystems enriched by deposition of marine-derived nutrients may see more 624 extensive algal blooms and thus increased BAR.

626 Anthropogenic activities may also affect nutrient delivery to snow and ice ecosystems.

627 Agricultural dust carries N, P, and K which can expand algal blooms on snowfields (Ganey et 628 al., 2017). Increases in temperature and drought will lead to an increase in fuel aridity, forest 629 fires, and corresponding increases in black carbon delivery to snow and ice (Kaspari et al., 630 2015; Keegan et al., 2014; Kim et al., 2005; Stevens-Rumann et al., 2018). While addition of 631 soot from forest fires will lower albedo and increase melt directly, it can also serve as a nutrient 
632 source. Finally, higher levels of atmospheric $\mathrm{CO}_{2}$ will likely increase snow algae primary

633 productivity and further a positive feedback loop between rising atmospheric $\mathrm{CO}_{2}$, algal

634 abundance, and BAR (Hamilton and Havig, 2020).

635

\section{Research gaps}

637 Below, we highlight gaps in our understanding of BAR in the cryosphere. Recent reviews have

638 highlighted research priorities for BAR studies including establishing algae culture collections

639 and sequencing algal genomes, measuring single cell reflectance spectra to facilitate remote

640 sensing, and improving modeling of BAR effects over increasing spatial scales (Edwards et al.,

641 2020; Hoham and Remias, 2020; Williamson et al., 2019). Here, we focus on gaps that have

642 either not been covered by previous efforts or we extend their points. We conclude by

643 highlighting one of the most valuable research gaps that remains to be filled: establishing a

644 long-term, global monitoring network for BAR.

645

646 Genomics

647 Biogeographic analyses of snow and ice algae have revealed similarities in population structure

648 across spatial and temporal scales (Lutz et al., 2018; Segawa et al., 2018). Connecting genes to

649 function in these communities, however, remains largely unexplored. Until recently, cutting-edge

650 genomic tools—such as long-read sequencing (Hotaling and Kelley, 2019)—have not been

651 applied to the cryosphere (Edwards et al., 2020; Williamson et al., 2019) although they likely

652 hold considerable potential for understanding the genomic basis of life on ice, including

653 phenotypic variation directly related to BAR (e.g., pigment production). The first genome of a

654 cryophilic algae was recently reported from a green algae-Chlamydomonas sp. ICE-L_that

655 lives in brine channels on Antarctic sea ice (Zhang et al., 2020). The genome of

656 Chlamydomonas sp. ICE-L includes expanded gene families related to DNA repair, likely in

657 response to the high UV radiation it encounters on sea ice (Zhang et al., 2020). While pigment 
658 production was not a focus of the study, the Chlamydomonas sp. ICE-L genome could be mined

659 for pigment-related genes (e.g., carotenogenesis genes; Takaichi, 2011) that could then be

660 integrated into a comparative framework as future BAR-related genomes become available.

661 Similarly, integrating transcriptomics, for instance, into a developmental time-series of algal

662 growth may aid in the identification of key genes underlying the transition from green to red

663 cysts (and associated pigment production) in snow algae and purple pigmentation in ice algae.

665 Understudied regions

666 The location, seasonality, and global extent of permanent snow and ice ecosystems means vast

667 areas remain understudied, especially for BAR. Understudied high-latitude areas include (but

668 are not limited to) the Russian Arctic, most of Antarctica, and northwestern and eastern

669 Greenland. A variety of temperate regions have also been overlooked, including subranges of

670 the Rocky Mountains in North America (e.g., Teton Range, USA), the Caucasus Mountains in

671 eastern Europe (e.g., Makowska et al., 2020), and similar localities. Rapidly receding tropical

672 glaciers are also urgent targets for ecological studies (Veettil and Kamp, 2019; Zawierucha and

673 Shain, 2019). Tropical glaciers, for instance, show far greater variability in terms of climate

674 sensitivity (Kaser, 2001; Kaser et al., 2004) compared to mid- and high-latitude glaciers and

675 differ from higher latitude glaciers by the absence of seasonal temperature cycles (monthly

676 mean temperatures vary by less than $5^{\circ} \mathrm{C}$ ) and extended periods of freezing (Lentini et al.,

677 2011). Due to their high altitude, tropical glaciers receive higher levels of energy forcing and are

678 particularly susceptible to increasing temperatures and shifting precipitation regimes (Chevallier

679 et al., 2011). Typical snow and ice algae have been reported from equatorial glaciers and are

680 likely contributing to BAR in analogous ways to other snow and ice ecosystems. However, the

681 absence of seasonal temperature cycles and extended periods of freezing may allow biota to be

682 active, and in the case of algae, even bloom throughout the year. Thus, unlike higher latitude

683 glaciers, algal impact on BAR in equatorial regions may not be restricted to melt seasons. 


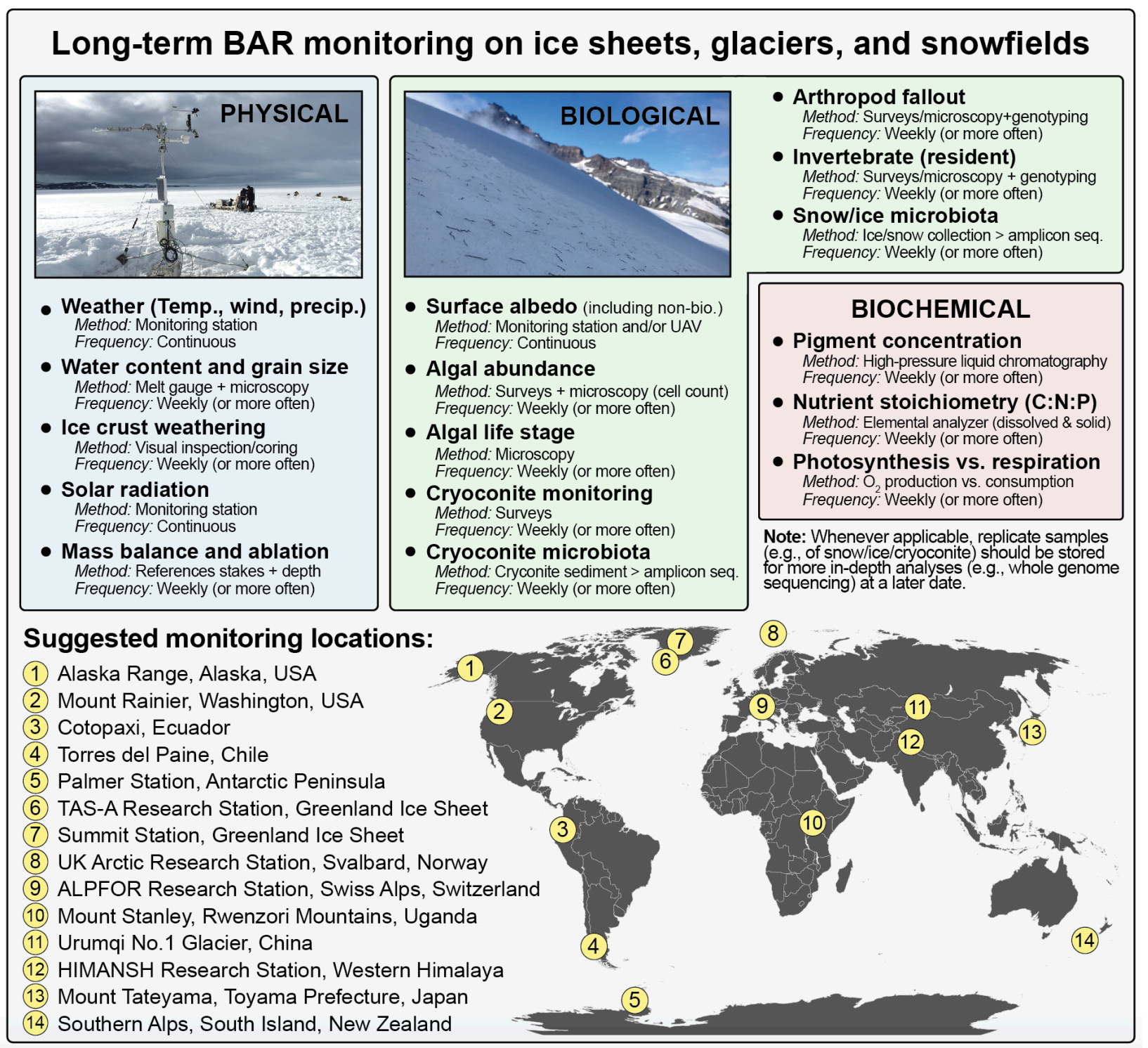

Figure 5. A proposed global framework for long-term monitoring of biological albedo reduction (BAR) on ice sheets, glaciers, and snowfields. Recommended focal variables and frequency of data collection are were selected to strike a balance between the value of the inference and often limited resources and minimal research infrastructure where monitoring is most needed. Proposed monitoring locations span a global gradient of elevation, latitude, and longitude, while also being in close proximity to existing research stations or long-term projects where possible. Photo credits: @ Andres Ahlstrøm/GEUS (left) and (c) Scott Hotaling (right).

\section{Temporal sampling}

694 Given the degree that seasonal variation can influence BAR, temporal sampling for full, explicitly defined, melt seasons are conspicuously lacking. Ideally, temporal perspectives during melt 
seasons should be complemented by year-round sampling of snow and ice to generate

697 reference information about dominant winter processes and associated biotic communities.

698 Similarly, latitudinal comparisons of seasonality across a gradient of day lengths from temperate

699 to polar regions will shed important information on how light availability and related factors may

700 influence melt season processes and ultimately BAR.

701

702 Long-term BAR monitoring

703 Our ability to monitor the feedbacks between BAR and climate change is limited by the fact that

704 no glacier biology monitoring programs exist. Long-term environmental data are collected by

705 weather stations on some glaciers and ice sheets (e.g., PROMICE on the Greenland ice sheet)

706 and if linked to data associated with abiotic and biotic drivers of albedo reduction, they could

707 provide a key data set for monitoring and quantifying BAR. However, environmental data alone,

708 especially from a single location, will not substantially improve global understanding of BAR nor

709 provide an opportunity to track changes. A global call for collaboration, including existing

710 networks (e.g., International Network for Terrestrial Research and Monitoring in the Arctic,

711 INTERACT), could be used to bring the necessary partners together. Here, we propose a global

712 framework (outlined in Fig. 5) for long-term monitoring of BAR that integrates 16 environmental

713 variables spanning the physical, biological, and biochemical sciences to be collected at 14

714 locations around the world. A global, and thus representative, data set can only be gained

715 through coordinated effort. Such a program could begin with one or several select sites, in

716 particular those that are staffed year-round. As part of this effort, protocols should be

717 established, refined, and published. The effort could then be expanded to new sites as

718 resources allow.

719

720 Towards a global comparative framework 
721 One overarching goal for BAR research in the cryosphere-testing and quantifying the effects of

722 all potential drivers, from microbes to humans-will always be challenging due to the many

723 unknowns discussed in this review, the complexity of interactions between biotic and abiotic

724 factors, and the difficulty of comparing results at different spatial and temporal scales. However,

725 one major challenge for the field—-the difficulty of making comparisons among studies-is

726 largely an issue of coordination and can be improved more easily. The development of an

727 integrative monitoring program with protocols developed through collaboration and shared

728 across research groups would greatly improve comparability of results (see Fig. 5). Similarly,

729 standardizing approaches for measuring albedo, including instrument configuration, are key and

730 have been discussed previously (Cook et al., 2017a). Finally, greater consistency in the

731 terminology used to refer to both the phenomenon and taxa being discussed is needed. To this

732 end, we recommend that the effects of biotic factors on albedo reduction be referred to as

733 biological albedo reduction (BAR; Cook et al., 2020a). Researchers should also take care to

734 specify if their focus is on terrestrial or marine algae. In the terrestrial realm, we recommend the

735 phrase "glacier algae" be reserved for collectively referring to all algae inhabiting glacier snow

736 and ice habitats with specific groups differentiated by "ice algae" and "snow algae" therein.

738 Conclusion:

739 The global cryosphere is in precipitous decline due to a host of factors, mainly a warming

740 climate. Both biotic and abiotic impurities in snow and ice reduce albedo and increase

741 absorption of solar radiation, furthering melt. In this review, we provided a global synthesis of

742 BAR in the cryosphere, including both well-known drivers and others that may be overlooked.

743 We identified gaps in our current understanding of BAR and key areas where future research

744 efforts should focus. However, the most significant challenges for the field are the need for long-

745 term monitoring of BAR in a coordinated fashion paired with increasing the comparability of

746 results across studies. To this end, we recommend future studies incorporate more 
747 standardized methods, including reporting of specific metadata. Collectively, we hope this

748 review spurs an expanded view of BAR in the cryosphere and leads to more synthetic

749 understanding of its drivers.

750

751 Acknowledgements:

752 S.H. and J.L.K. were supported by NSF awards OPP-1906015 and IOS-1557795. S.L. and

753 L.G.B. were supported by the Helmholtz Recruiting Initiative (I-044-16-01). R.J.D. was

754 supported by a National Institute for Water Resources grant (2018AK141B) and a NASA Alaska

755 Space Grant. A.M.A., L.G.B., and J.M. acknowledge funding from UK NERC (NE/M020770/1).

756 A.M.A. and L.G.B. acknowledge support from the ERC Synergy grant (Deep Purple, 856416).

757 N.T. acknowledges support from the Arctic Challenge for Sustainability II (JPMXD1420318865).

758 T.L.H. was supported by NSF award EAR-1904159.

759

760 Author contributions:

761 S.H. and T.L.H. conceived of the review and defined its framework. All authors contributed

762 content, editing, and approved the final version for submission.

763

764 Competing Interests:

765 The authors declare no competing interests.

766

767 References:

768 Andrews, T.D., MacKay, G., Andrew, L., 2012. Archaeological Investigations of Alpine Ice 769 Patches in the Selwyn Mountains, Northwest Territories, Canada. Arctic 65, 1-21.

770 Anesio, A.M., Hodson, A.J., Fritz, A., Psenner, R., Sattler, B., 2009. High microbial activity on

771 glaciers: importance to the global carbon cycle. Glob. Change Biol. 15, 955-960.

$772 \quad$ https://doi.org/10.1111/j.1365-2486.2008.01758.x 
773 Anesio, A.M., Laybourn-Parry, J., 2012. Glaciers and ice sheets as a biome. Trends Ecol. Evol. 27, 219-225. https://doi.org/10.1016/j.tree.2011.09.012

Anesio, A.M., Lutz, S., Chrismas, N.A.M., Benning, L.G., 2017. The microbiome of glaciers and ice sheets. Npj Biofilms Microbiomes 3, 10-10. https://doi.org/10.1038/s41522-017-

Anesio, A.M., Mindl, B., Laybourn-Parry, J., Hodson, A.J., Sattler, B., 2007. Viral dynamics in cryoconite holes on a high Arctic glacier (Svalbard): Viruses in cyroconite holes. J. Geophys. Res. Biogeosciences 112, n/a--n/a. https://doi.org/10.1029/2006jg000350

Antor, R.J., 1995. The Importance of Arthropod Fallout on Snow Patches for the Foraging of High-Alpine Birds. J. Avian Biol. 26, 81. https://doi.org/10.2307/3677216

Aoki, T., Hachikubo, A., Hori, M., 2003. Effect of snow physical parameters on shortwave broadband albedos. J. Geophys. Res. Atmospheres 108, 1-12. https://doi.org/10.1029/2003jd003506

Azzoni, R.S., Franzetti, A., Fontaneto, D., Zullini, A., Ambrosini, R., Ambrosini, \& R., 2015. Nematodes and rotifers on two Alpine debris-covered glaciers Nematodes and rotifers on two Alpine debris-covered glaciers. Italian Journal of Zoology 82, 616-623. https://doi.org/10.1080/11250003.2015.1080312

Baccolo, G., Di Mauro, B., Massabò, D., Clemenza, M., Nastasi, M., Delmonte, B., Prata, M., Prati, P., Previtali, E., Maggi, V., 2017. Cryoconite as a temporary sink for anthropogenic species stored in glaciers. Sci. Rep. 7, 1-11. https://doi.org/10.1038/s41598-017-10220-

Bellas, C.M., Anesio, A.M., Telling, J., Stibal, M., Tranter, M., Davis, S., 2013. Viral impacts on 795 bacterial communities in Arctic cryoconite. Environ. Res. Lett. 8, 45021-45021.

796 https://doi.org/10.1088/1748-9326/8/4/045021 
797 Bellas, C.M., Schroeder, D.C., Edwards, A., Barker, G., Anesio, A.M., 2020. Flexible genes establish widespread bacteriophage pan-genomes in cryoconite hole ecosystems. Nat. Commun. 11, 4403. https://doi.org/10.1038/s41467-020-18236-8

Boetius, A., Anesio, A.M., Deming, J.W., Mikucki, J.A., Rapp, J.Z., 2015. Microbial ecology of the cryosphere: sea ice and glacial habitats. Nat. Rev. Microbiol. 13, 677-690. https://doi.org/10.1038/nrmicro3522

Bøggild, C.E., Brandt, R.E., Brown, K.J., Warren, S.G., 2010. The ablation zone in northeast

Bourgeois, J.C., 1990. A modern pollen spectrum from Dye 3, South Greenland Ice Sheet, Journal of Glaciology.

Bourgeois, J.C., Gajewski, K., Koerner, R.M., 2001. Spatial patterns of pollen deposition in arctic snow. J. Geophys. Res. Atmospheres 106, 5255-5265. https://doi.org/10.1029/2000JD900708

814 Bullard, J.E., Baddock, M., Bradwell, T., Crusius, J., Darlington, E., Gaiero, D., Gassó, S.,

Box, J.E., Fettweis, X., Stroeve, J.C., Tedesco, M., Hall, D.K., Steffen, K., 2012. Greenland ice sheet albedo feedback: Thermodynamics and atmospheric drivers. Cryosphere 6, 821-

Cameron, K.A., Hodson, A.J., Osborn, A.M., 2012. Structure and diversity of bacterial, Gisladottir, G., Hodgkins, R., McCulloch, R., McKenna-Neuman, C., Mockford, T., Stewart, H., Thorsteinsson, T., 2016. High-latitude dust in the Earth system. Rev. eukaryotic and archaeal communities in glacial cryoconite holes from the Arctic and the Antarctic. FEMS Microbiol. Ecol. 82, 254-267. https://doi.org/10.1111/j.15746941.2011.01277.x 
822 Cavicchioli, R., Ripple, W.J., Timmis, K.N., Azam, F., Bakken, L.R., Baylis, M., Behrenfeld, M.J., Boetius, A., Boyd, P.W., Classen, A.T., Crowther, T.W., Danovaro, R., Foreman, C.M., Huisman, J., Hutchins, D.A., Jansson, J.K., Karl, D.M., Koskella, B., Mark Welch, D.B., Martiny, J.B.H., Moran, M.A., Orphan, V.J., Reay, D.S., Remais, J.V., Rich, V.I., Singh, B.K., Stein, L.Y., Stewart, F.J., Sullivan, M.B., van Oppen, M.J.H., Weaver, S.C., Webb,

Chevallier, P., Pouyaud, B., Suarez, W., Condom, T., 2011. Climate change threats to environment in the tropical Andes: Glaciers and water resources. Reg. Environ. Change 11, 179-187. https://doi.org/10.1007/s10113-010-0177-6

Chrismas, N.A.M., Anesio, A.M., Sánchez-Baracaldo, P., 2018. The future of genomics in polar and alpine cyanobacteria. FEMS Microbiol. Ecol. 94. https://doi.org/10.1093/femsec/fiy032

Chrismas, N.A.M., Anesio, A.M., Sánchez-Baracaldo, P., 2015. Multiple adaptations to polar and alpine environments within cyanobacteria: a phylogenomic and Bayesian approach. Front. Microbiol. 6, 1070-1070. https://doi.org/10.3389/fmicb.2015.01070

Cook, J.M., Edwards, A., Takeuchi, N., Irvine-Fynn, T., 2016. Cryoconite: The dark biological secret of the cryosphere. Prog. Phys. Geogr. Earth Environ. 40, 66-111.

844 Cook, J.M., Hodson, A.J., Gardner, A.S., Flanner, M., Tedstone, A.J., Williamson, C., Irvine845 Fynn, T.D.L., Nilsson, J., Bryant, R., Tranter, M., 2017a. Quantifying bioalbedo: A new https://doi.org/10.1177/0309133315616574

Cook, J.M., Flanner, M., Williamson, C., Skiles, S.M., 2020a. Bio-optical Properties of Terrestrial Snow and Ice, in: Kokhanovsky, A. (Ed.), Springer Series in Light Scattering. Springer, Cham, pp. 129-163. physically based model and discussion of empirical methods for characterising biological 
influence on ice and snow albedo. Cryosphere 11, 2611-2632. https://doi.org/10.5194/tc-11-2611-2017

Cook, J.M., Hodson, A.J., Taggart, A.J., Mernild, S.H., Tranter, M., 2017b. A predictive model for the spectral "bioalbedo" of snow. J. Geophys. Res. Earth Surf. 122, 434-454. https://doi.org/10.1002/2016JF003932

Cook, J.M., Tedstone, A.J., Williamson, C., McCutcheon, J., Hodson, A.J., Dayal, A., Skiles, M., Hofer, S., Bryant, R., McAree, O., McGonigle, A., Ryan, J., Anesio, A.M., Irvine-Fynn, T.D.L., Hubbard, A., Hanna, E., Flanner, M., Mayanna, S., Benning, L.G., As, D. van,

Cordero, R.J.B., Robert, V., Cardinali, G., Arinze, E.S., Thon, S.M., Casadevall, A., 2018. Impact of Yeast Pigmentation on Heat Capture and Latitudinal Distribution. Curr. Biol. CB 28, 2657--2664. https://doi.org/10.1016/j.cub.2018.06.034

Coulson, S.J., Midgley, N.G., 2012. The role of glacier mice in the invertebrate colonisation of glacial surfaces: The moss balls of the Falljökull, Iceland. Polar Biol. 35, 1651-1658. https://doi.org/10.1007/s00300-012-1205-4

Culka, A., Jehlička, J., Ascaso, C., Artieda, O., Casero, C.M., Wierzchos, J., 2017. Raman microspectrometric study of pigments in melanized fungi from the hyperarid Atacama desert gypsum crust. J. Raman Spectrosc. 48, 1487-1493. https://doi.org/10.1002/jrs.5137

de Menezes, G.C.A., Amorim, S.S., Gonçalves, V.N., Godinho, V.M., Simões, J.C., Rosa, C.A., Rosa, L.H., 2019. Diversity, Distribution, and Ecology of Fungi in the Seasonal Snow of Antarctica. Microorganisms 7, 445-445. https://doi.org/10.3390/microorganisms7100445

Denali National Park and Preserve, 2019 (Statistical year in review. Mountaineering Summary Report-2019), 2019. 
873 Di Mauro, B., Garzonio, R., Baccolo, G., Franzetti, A., Pittino, F., Leoni, B., Remias, D., 874 Colombo, R., Rossini, M., 2020. Glacier algae foster ice-albedo feedback in the 875 European Alps. Sci. Rep. 10, 4739-4739. https://doi.org/10.1038/s41598-020-61762-0

876 Dial, R.J., Ganey, G.Q., Skiles, S.M., 2018. What color should glacier algae be? An ecological 877 role for red carbon in the cryosphere. FEMS Microbiol. Ecol. 94.

878 https://doi.org/10.1093/femsec/fiy007

879 Dial, R.J., Saunders, R., Lang, S.A., Lee, B., Wimberger, P., Dinapoli, M.S., Egiazarov, A.S., 880 Gipple, S.L., Maghirang, M.R., Swartley-McArdle, D.J., Yudkovitz, S.R., Shain, D.H., 2012. Historical biogeography of the North American glacier ice worm, Mesenchytraeus solifugus (Annelida: Oligochaeta: Enchytraeidae). Mol. Phylogenet. Evol. 63, 577-584. https://doi.org/10.1016/j.ympev.2012.01.008

Dickinson, R.E., 1995. Land processes in climate models. Remote Sens. Environ. 51, 27-38. https://doi.org/10.1016/0034-4257(94)00062-R

Diffenbaugh, N.S., Scherer, M., Ashfaq, M., 2013. Response of snow-dependent hydrologic extremes to continued global warming. Nat. Clim. Change 3, 379-384. https://doi.org/10.1038/nclimate1732

Durbin, D.V., 1975. The ecology of insects and other arthropods found on Sierran snowfields.

Edwards, A., Cameron, K.A., Cook, J.M., Debbonaire, A.R., Furness, E., Hay, M.C., Rassner, S.M.E., 2020. Microbial genomics amidst the arctic crisis. Microb. Genomics 6, 1-20. https://doi.org/10.1099/mgen.0.000375

Edwards, A., Douglas, B., Anesio, A.M., Rassner, S.M., Irvine-Fynn, T.D.L., Sattler, B., Griffith, G.W., 2013. A distinctive fungal community inhabiting cryoconite holes on glaciers in Svalbard. Fungal Ecol. 6, 168-176. https://doi.org/10.1016/j.funeco.2012.11.001 179. https://doi.org/10.1146/annurev.ento.32.1.163 
898

899

900

901

902

903

904

905

906

907

908

909

910

911

912

913

914

915

916

917

918

919

920

921

Edwards, J.S., Banko, P.C., 1976. Arthropod Fallout and Nutrient Transport: A Quantitative Study of Alaskan Snowpatches. Arct. Alp. Res. 8, 237-245. https://doi.org/10.1080/00040851.1976.12004021

Farnell, R., Hare, P.G., Blake, E., Bowyer, V., Schweger, C., Greer, S., Gotthardt, R., 2004. Multidisciplinary Investigations of Alpine Ice Patches in Southwest Yukon, Canada: Paleoenvironmental and Paleobiological Investigations. Arctic 57, 247-259.

Fiera, C., 2014. Application of stable isotopes and lipid analysis to understand trophic interactions in springtails. North-West. J. Zool. 10, 227-235.

Filipiak, M., 2016. Pollen stoichiometry may influence detrital terrestrial and aquatic food webs. Front. Ecol. Evol. 4, 1-8. https://doi.org/10.3389/fevo.2016.00138

Fountain, A.G., Campbell, J.L., Schuur, E.A.G., Stammerjohn, S.E., Williams, M.W., Ducklow, H.W., 2012. The Disappearing Cryosphere: Impacts and Ecosystem Responses to Rapid Cryosphere Loss. BioScience 62, 405-415. https://doi.org/10.1525/bio.2012.62.4.11

Fountain, A.G., Nylen, T.H., Tranter, M., Bagshaw, E., 2008. Temporal variations in physical and chemical features of cryoconite holes on Canada Glacier, McMurdo Dry Valleys, Antarctica. J. Geophys. Res. Biogeosciences 113, n/a-n/a. https://doi.org/10.1029/2007JG000430

French, S.P., French, M.G., Knight, R.R., 1994. Grizzly Bear Use of Army Cutworm Moths in the Yellowstone Ecosystem. Bears Their Biol. Manag. 9, 389-389. https://doi.org/10.2307/3872725

Fretwell, P.T., Trathan, P.N., 2009. Penguins from space: faecal stains reveal the location of emperor penguin colonies. Glob. Ecol. Biogeogr. 18, 543-552. https://doi.org/10.1111/j.1466-8238.2009.00467.x 
922 Fujii, M., Takano, Y., Kojima, H., Hoshino, T., Tanaka, R., Fukui, M., 2009. Microbial community structure, pigment composition, and nitrogen source of red snow in Antarctica. Microb. Ecol. 59, 466-475. https://doi.org/10.1007/s00248-009-9594-9

Ganey, G.Q., Loso, M.G., Burgess, A.B., Dial, R.J., 2017. The role of microbes in snowmelt and radiative forcing on an Alaskan icefield. Nat. Geosci. 10, 754-759. https://doi.org/10.1038/ngeo3027

Goodman, D., 1971. Ecological investigations of ice worms on Casement Glacier, Southeastern Alaska. Inst. Polar Stud. Rep. No 39.

Goodwin, K., Loso, M.G., Braun, M., 2012. Glacial Transport of Human Waste and Survival of Fecal Bacteria on Mt. McKinley's Kahiltna Glacier, Denali National Park, Alaska. Arct. Antarct. Alp. Res. 44, 432-445. https://doi.org/10.1657/1938-4246-44.4.432

Gray, A., Krolikowski, M., Fretwell, P., Convey, P., Peck, L.S., Mendelova, M., Smith, A.G., Davey, M.P., 2020. Remote sensing reveals Antarctic green snow algae as important terrestrial carbon sink. Nat. Commun. 11. https://doi.org/10.1038/s41467-020-16018-w

Grenfell, T.C., Light, B., 2002. Spatial distribution and radiative effects of soot in the snow and sea ice during the SHEBA experiment. J. Geophys. Res. 107, 8032. https://doi.org/10.1029/2000JC000414

Groisman, P.Y., Karl, T.R., Knight, R.W., 1994. Observed Impact of Snow Cover on the Heat Balance and the Rise of Continental Spring Temperatures. Science 263, 198-200.

944 Hadley, O.L., Kirchstetter, T.W., 2012. Black-carbon reduction of snow albedo. Nat. Clim.

$945 \quad$ Change 2, 437-440. https://doi.org/10.1038/nclimate1433 
946 Hagemoen, R.I.M., Reimers, E., 2002. Reindeer summer activity pattern in relation to weather and insect harassment. J. Anim. Ecol. 71, 883-892. https://doi.org/10.1046/j.1365-

Hallmann, C.A., Sorg, M., Jongejans, E., Siepel, H., Hofland, N., Schwan, H., Stenmans, W., Müller, A., Sumser, H., Hörren, T., Goulson, D., de Kroon, H., 2017. More than 75

Hamilton, T.L., Havig, J., 2017. Primary productivity of snow algae communities on stratovolcanoes of the Pacific Northwest. Geobiology 15.

Hamilton, T.L., Havig, J.R., 2020. Inorganic carbon addition stimulates snow algae primary productivity. ISME J. 14, 857-860. https://doi.org/10.1038/s41396-018-0048-6

Hansen, J., Nazarenko, L., 2003. Soot climate forcing via snow and ice albedos. Proc. Natl. Acad. Sci. 101, 423-428. https://doi.org/10.1073/pnas.2237157100

Hansen, J., Ruedy, R., Sato, M., Lo, K., 2010. Global surface temperature change. Rev. Geophys. 48. https://doi.org/10.1029/2010RG000345

Hansen, R.R., Hansen, O.L.P., Bowden, J.J., Normand, S., Bay, C., Sørensen, J.G., Høye, T.T., 2016. High spatial variation in terrestrial arthropod species diversity and composition

Hanzer, F., Förster, K., Nemec, J., Strasser, U., 2018. Projected cryospheric and hydrological near the Greenland ice cap. Polar Biol. 39, 2263-2272. https://doi.org/10.1007/s00300impacts of 21st century climate change in the Ötztal Alps (Austria) simulated using a physically based approach. Hydrol. Earth Syst. Sci. 22, 1593-1614. https://doi.org/10.5194/hess-22-1593-2018 
970 Hardy, D.R., Hardy, S.P., 2008. White-winged Diuca Finch (Diuca speculifera) Nesting on Quelccaya Ice Cap, Perú. Wilson J. Ornithol. 120, 613-617. https://doi.org/10.1676/06165.1

973 Hardy, S.P., Hardy, D.R., Gil, K.C., 2018. Avian nesting and roosting on glaciers at high 974 elevation, Cordillera Vilcanota, Peru. Wilson J. Ornithol. 130, 940-940.

$975 \quad$ https://doi.org/10.1676/1559-4491.130.4.940

976 Hare, P.G., Thomas, C.D., Topper, T.N., Gotthardt, R., 2012. The Archaeology of Yukon Ice 977 Patches: New Artifacts, Observations, and Insights. Arctic 65, 118-135.

978 Harrold, Z.R., Hausrath, E.M., Garcia, A.H., Murray, A.E., Tschauner, O., Raymond, J.A., 979

Hartz, T.K., Johnstone, P.R., 2006. Nitrogen availability from high-nitrogen-containing organic Huang, S., 2018. Bioavailability of Mineral-Bound Iron to a Snow Algal-Bacterial fertilizers. HortTechnology 16, 39-42. https://doi.org/10.21273/horttech.16.1.0039

Hartzell, P.L., Nghiem, J.V., Richio, K.J., Shain, D.H., 2005. Distribution and phylogeny of glacier ice worms (Mesenchytraeus solifugus and Mesenchytraeus solifugus rainierensis

Havig, J.R., Hamilton, T.L., 2019. Snow algae drive productivity and weathering at volcanic rock-hosted glaciers. Geochim. Cosmochim. Acta 247, 220-242. https://doi.org/10.1016/j.gca.2018.12.024

Hayashi, K., Cooper, E.J., Loonen, M.J.J.E., Kishimoto-Mo, A.W., Motohka, T., Uchida, M., Nakatsubo, T., 2014. Potential of Svalbard reindeer winter droppings for emission/absorption of methane and nitrous oxide during summer. Polar Sci. 8, 196206. https://doi.org/10.1016/j.polar.2013.11.002

Heinrich, R., Bell, R., 1995. Winter Food of a Small Insectivorous Bird, the Golden-Crowned Kinglet on JSTOR. Wilson Bull. 558-561. 
996

Hell, K., Edwards, A., Zarsky, J., Podmirseg, S.M., Girdwood, S., Pachebat, J.A., Insam, H., Sattler, B., 2013. The dynamic bacterial communities of a melting High Arctic glacier snowpack. ISME J. 7, 1814-1826. https://doi.org/10.1038/ismej.2013.51

Henderson, K.A., 1933. The Wind River Range of Wyoming II. Appalaciha 19, 354-375.

Hock, R., Bliss, A., Marzeion, B., Giesen, R.H., Hirabayashi, Y., Huss, M., Radić, V., Slangen, A.B.A., 2019. GlacierMIP - A model intercomparison of global-scale glacier massbalance models and projections. J. Glaciol. 65, 453-467. https://doi.org/10.1017/jog.2019.22

Hodson, A., Anesio, A.M., Ng, F., Watson, R., Quirk, J., Irvine-Fynn, T., Dye, A., Clark, C., McCloy, P., Kohler, J., Sattler, B., 2007. A glacier respires: Quantifying the distribution and respiration $\mathrm{CO} 2$ flux of cryoconite across an entire Arctic supraglacial ecosystem: Respiration rates upon an arctic glacier. J. Geophys. Res. Biogeosciences 112, n/a--n/a. https://doi.org/10.1029/2007jg000452

Hodson, A., Anesio, A.M., Tranter, M., Fountain, A., Osborn, M., Priscu, J., Laybourn-Parry, J., Sattler, B., 2008. Glacial ecosystems. Ecol. Monogr. 78, 41-67. https://doi.org/10.1890/07-0187.1

Hodson, A., Bøggild, C., Hanna, E., Huybrechts, P., Langford, H., Cameron, K., Houldsworth, A., 2010. The cryoconite ecosystem on the Greenland ice sheet. Ann. Glaciol. 51, 123129. https://doi.org/10.3189/172756411795931985

Hofer, S., Tedstone, A.J., Fettweis, X., Bamber, J.L., 2017. Decreasing cloud cover drives the recent mass loss on the Greenland Ice Sheet. Sci. Adv. 3, e1700584-e1700584. https://doi.org/10.1126/sciadv.1700584

Hoham, R., Duval, B., 2001. Microbial Ecology of Snow and Freshwater Ice with Emphasis on Snow Algae, in: Jones, H.G., Pomeroy, J.W., Walker, D.A., Hoham, R.W. (Eds.), Snow Ecology: An Interdisciplinary Examination of Snow-Covered Ecosystems. Cambridge University Press, pp. 168-228. 
1022 Hoham, R.W., Remias, D., 2020. Snow and Glacial Algae: A Review. J. Phycol. 56, 264-282. $1023 \quad$ https://doi.org/10.1111/jpy.12952

1024 Hotaling, S., Bartholomaus, T.C., Gilbert, S.L., 2020. Rolling stones gather moss: movement 1025 1026 and longevity of moss balls on an Alaskan glacier. Polar Biol. 43, 735-744. https://doi.org/10.1007/s00300-020-02675-6

Hotaling, S., Finn, D.S., Giersch, J., Weisrock, D.W., Jacobsen, D., 2017a. Climate change and

Hotaling, S., Hood, E., Hamilton, T.L., 2017b. Microbial ecology of mountain glacier ecosystems: biodiversity, ecological connections and implications of a warming climate. Environ. Microbiol. 19. https://doi.org/10.1111/1462-2920.13766

Hotaling, S., Kelley, J.L., 2019. The rising tide of high-quality genomic resources. Mol. Ecol. Resour. 19, 567-569. https://doi.org/10.1111/1755-0998.12964

Hotaling, S., Shain, D.H., Lang, S.A., Bagley, R.K., Tronstad, L.M., Weisrock, D.W., Kelley, J.L., 2019a. Long-distance dispersal, ice sheet dynamics and mountaintop isolation underlie the genetic structure of glacier ice worms. Proc. Biol. Sci. 286, 20190983-20190983. https://doi.org/10.1098/rspb.2019.0983

Hotaling, S., Wimberger, P.H., Kelley, J.L., Watts, H.E., 2019b. Macroinvertebrates on glaciers: a key resource for terrestrial food webs? Ecology 101, e02947-e02947. https://doi.org/10.1002/ecy.2947

Hu, Q., Feng, S., 2002. Interannual rainfall variations in the North American summer monsoon region: 1900-98. J. Clim. 15, 1189-1202.

1044 Hughes, L., Bazzaz, F.A., 2001. Effects of elevated CO2 on five plant-aphid interactions. Entomol. Exp. Appl. 99, 87-96. https://doi.org/10.1046/j.1570-7458.2001.00805.x

1046 Huss, M., Hock, R., 2018. Global-scale hydrological response to future glacier mass loss. Nat. 1047 Clim. Change 8, 135-140. https://doi.org/10.1038/s41558-017-0049-x 
1048

1049

1050

1051

1052

\section{3}

1054

1055

1056

1057

1058

1059

1060

1061

1062

1063

1064

1065

1066

1067

1068

1069

1070

1071

1072

IPCC, 2019. Special Report on the Ocean and Cryosphere in a Changing Climate — Just another IPCC site.

Irvine-Fynn, T.D.L., Edwards, A., 2014. A frozen asset: The potential of flow cytometry in constraining the glacial biome: Communication to the Editor. Cytometry A 85, 3-7. https://doi.org/10.1002/cyto.a.22411

Irvine-Fynn, T.D.L., Edwards, A., Newton, S., Langford, H., Rassner, S.M., Telling, J., Anesio, A.M., Hodson, A.J., 2012. Microbial cell budgets of an Arctic glacier surface quantified using flow cytometry: Arctic supraglacial microbial cell budgets. Environ. Microbiol. 14, 2998-3012. https://doi.org/10.1111/j.1462-2920.2012.02876.x

Ishikawa, S., Osamu, M., Kouichi, K., 1986. Snow algal blooms and their habitat conditions observed at Syowa Station, Antarctica. Mem. Natl. Inst. Polar Res. Spec. Issue 191197.

Jones, D.B., Harrison, S., Anderson, K., Whalley, W.B., 2019. Rock glaciers and mountain hydrology: A review. Earth-Sci. Rev. 193, 66-90. https://doi.org/10.1016/j.earscirev.2019.04.001

Kaczmarek, Ł., Jakubowska, N., Celewicz-Gołdyn, S., Zawierucha, K., 2015. The microorganisms of cryoconite holes (algae, Archaea, bacteria, cyanobacteria, fungi, and Protista): a review. Polar Rec. 52, 176-203. https://doi.org/10.1017/s0032247415000637

Kaser, G., 2001. Glacier-climate interaction at low latitudes. J. Glaciol. 47, 195-204. https://doi.org/10.3189/172756501781832296

Kaser, G., Hardy, D.R., Mölg, T., Bradley, R.S., Hyera, T.M., 2004. Modern glacier retreat on Kilimanjaro as evidence of climate change: observations and facts. Int. J. Climatol. 24, 329-339. https://doi.org/10.1002/joc.1008

Kaspari, S., McKenzie Skiles, S., Delaney, I., Dixon, D., Painter, T.H., 2015. Accelerated glacier melt on Snow Dome, Mount Olympus, Washington, USA, due to deposition of black 
1073

1074

1075

1076

1077

\section{8}

1079

1080

1081

1082

1083

1084

1085

1086

1087

1088

1089

1090

1091

1092

1093

1094

1095

1096

1097

1098

carbon and mineral dust from wildfire. J. Geophys. Res. Atmospheres 120, 2793-2807. https://doi.org/10.1002/2014JD022676

Keegan, K.M., Albert, M.R., McConnell, J.R., Baker, I., 2014. Climate change and forest fires synergistically drive widespread melt events of the Greenland Ice Sheet. Proc. Natl. Acad. Sci. U. S. A. 111, 7964-7967. https://doi.org/10.1073/pnas.1405397111

Kellerman, A.M., Hawkings, J.R., Wadham, J.L., Kohler, T.J., Stibal, M., Grater, E., Marshall, M., Hatton, J.E., Beaton, A., Spencer, R.G.M., 2020. Glacier Outflow Dissolved Organic Matter as a Window Into Seasonally Changing Carbon Sources: Leverett Glacier, Greenland. J. Geophys. Res. Biogeosciences 125. https://doi.org/10.1029/2019jg005161

Khan, A.L., Dierssen, H., Scambos, T., Höfer, J., Cordero, R.R., 2020. Spectral characterization, radiative forcing, and pigment content of coastal Antarctic snow algae: approaches to spectrally discriminate red and green communities and their impact on snowmelt. Cryosphere Discuss. preprint-preprint. https://doi.org/10.5194/tc-2020-170

Kim, Y., Hatsushika, H., Muskett, R.R., Yamazaki, K., 2005. Possible effect of boreal wildfire soot on Arctic sea ice and Alaska glaciers. Atmos. Environ. 39, 3513-3520. https://doi.org/10.1016/j.atmosenv.2005.02.050

Knowles, N., Dettinger, M.D., Cayan, D.R., 2006. Trends in snowfall versus rainfall in the western United States. J. Clim. 19, 4545-4559. https://doi.org/10.1175/JCLI3850.1

Kohshima, S., 1984. A novel cold-tolerant insect found in a Himalayan glacier. Nature 310, 225227. https://doi.org/10.1038/310225a0

Kohshima, S., Seko, K., Yoshimura, Y., 1992. Biotic Acceleration of Glacier Melting in Yala Glacier 9 Langtang Region, Nepal Himalaya. IAHS Publ.

Kol, E., Peterson, J.A., 1976. Cryobiology, in: Hope, G.S., Peterson, J.A., Radok, U., Allison, I. (Eds.), The Equatorial Glaciers of New Guinea. Balkema, Rotterdam, pp. 81-91.

Koshkarev, B.P., 1984. Characteristics of Snow Leopard (Uncia uncia) Movements in the Tien Shan, Int. Ped. Book of Snow leopards. 
1099

1100

1101

1102

1103

1104

1105

1106

1107

1108

1109

1110

1111

1112

1113

1114

1115

1116

1117

1118

1119

1120

1121

1122

1123

1124

Krasting, J.P., Broccoli, A.J., Dixon, K.W., Lanzante, J.R., 2013. Future Changes in Northern Hemisphere Snowfall. J. Clim. 26, 7813-7828. https://doi.org/10.1175/JCLI-D-1200832.1

Krug, L., Erlacher, A., Markut, K., Berg, G., Cernava, T., 2020. The microbiome of alpine snow algae shows a specific inter-kingdom connectivity and algae-bacteria interactions with supportive capacities. ISME J. 1-14. https://doi.org/10.1038/s41396-020-0677-4

Lee, C.M., 2012. Withering Snow and Ice in the Mid-latitudes: A New Archaeological and Paleobiological Record for the Rocky Mountain Region. Arctic 65, 165-177.

Lentini, G., Cristofanelli, P., Duchi, R., Marinoni, A., Verza, G., Vuillermoz, E., Toffolon, R., Bonasoni, P., 2011. Mount Rwenzori (4750 M A.S.L., Uganda): Meteorological characterization and air-mass transport analysis. Geogr. Fis. E Din. Quat. 34, 183-193. https://doi.org/10.4461/GFDQ.2011.34.17

Leya, T., Rahn, A., Lütz, C., Remias, D., 2009. Response of arctic snow and permafrost algae to high light and nitrogen stress by changes in pigment composition and applied aspects for biotechnology. FEMS Microbiol. Ecol. 67, 432-443. https://doi.org/10.1111/j.1574$6941.2008 .00641 . x$

Lin, G., Penner, J.E., Flanner, M.G., Sillman, S., Xu, L., Zhou, C., 2014. Radiative forcing of organic aerosol in the atmosphere and on snow: Effects of SOA and brown carbon. J. Geophys. Res. Atmospheres 119, 7453-7476. https://doi.org/10.1002/2013jd021186

Lockwood, J.A., Debrey, L.D., Thompson, C.D., Love, C.M., Nunamaker, R.A., Shaw, S.R., Schell, S.P., Bomar, C.R., 1994. Preserved Insect Fauna of Glaciers of Fremont County in Wyoming: Insights into the Ecology of the Extinct Rocky Mountain Locust. Environ. Entomol. 23, 220-235. https://doi.org/10.1093/EE/23.2.220

Lockwood, J.A., Schell, S.P., Wangberg, J.K., Debrey, L.D., Debrey, W.G., Bomar, C.R., 1992. Preserved Insects and Physical Condition of Grasshopper Glacier. Arct. Alp. Res. 24, 229-232. https://doi.org/10.1080/00040851.1992.12002950 
1125 Lockwood, J.A., Thompson, C.D., Debrey, L.D., Love, C.M., Nunamaker, R.A., Pfadt, R.E., 1991. Preserved grasshopper fauna of Knife Point Glacier, Fremont County, Wyoming,

Lutz, S., Anesio, A.M., Edwards, A., Benning, L.G., 2016a. Linking microbial diversity and USA. Arct. Alp. Res. 23, 108-114. https://doi.org/10.2307/1551444

Lutz, S., Anesio, A.M., Edwards, A, Benning, L.G., 2016a. Linking microbial diverity and functionality of Arctic glacial surface habitats. Environ. Microbiol. 19, 551-565. https://doi.org/10.1111/1462-2920.13494

Lutz, S., Anesio, A.M., Edwards, A., Benning, L.G., 2015. Microbial diversity on Icelandic glaciers and ice caps. Front. Microbiol. 6, 307-307. https://doi.org/10.3389/fmicb.2015.00307

Lutz, S., Anesio, A.M., Raiswell, R., Edwards, A., Newton, R.J., Gill, F., Benning, L.G., 2016b. The biogeography of red snow microbiomes and their role in melting arctic glaciers. Nat. Commun. 7, 11968-11968. https://doi.org/10.1038/ncomms11968

Lutz, S., McCutcheon, J., McQuaid, J.B., Benning, L.G., 2018. The diversity of ice algal communities on the Greenland Ice Sheet as revealed by oligotyping. Microb. Genomics 4. https://doi.org/10.1099/mgen.0.000159

Lutz, S., Ziolkowski, L.A., Benning, L.G., 2019. The Biodiversity and Geochemistry of Cryoconite Holes in Queen Maud Land, East Antarctica. Microorganisms 7, 160-160. https://doi.org/10.3390/microorganisms7060160

Madsen, D.B., 2000. A high-elevation Allerød-Younger Dryas megafauna from the west-central Rocky Mountains, in: Madsen, D.B., Metcalf, M.D. (Eds.), Intermountain Archaeology. Anthropological Papers 122. University of Utah, Salt Lake City, pp. 100-115.

Makowska, N., Zawierucha, K., Nadobna, P., Piątek-Bajan, K., Krajewska, A., Szwedyk, J., Iwasieczko, P., Mokracka, J., Koczura, R., 2020. Occurrence of integrons and antibiotic resistance genes in cryoconite and ice of Svalbard, Greenland, and the Caucasus glaciers. Sci. Total Environ. 716, 137022. https://doi.org/10.1016/j.scitotenv.2020.137022 
1151 Mani, M.S., 1968. General Entomology. Oxford and IBH Publishing Co, Calcutta.

1152 Mann, D.H., Edwards, J.S., Gara, R.I., 1980. Diel Activity Patterns in Snowfield Foraging

1153 Invertebrates on Mount Rainier, Washington. Arct. Alp. Res. 12, 359-359.

$1154 \quad$ https://doi.org/10.2307/1550722

1155 Masutti, L., Covassi, M., 1978. Imenotteri Sinfiti di habitat forestali e montani del Friuli. Redia $1156 \quad 61,107-174$.

1157 McCutcheon, J., Lutz, S., Williamson, C., Cook, J.M., Tedstone, A.J., Vanderstraeten, A.,

1158 Wilson, S.A., Stockdale, A., Bonneville, S., Anesio, A.M., Yallop, M.L., McQuaid, J.B.,

1159 Tranter, M., Benning, L.G., 2021. Mineral phosphorus drives glacier algal blooms on the

1160 Greenland Ice Sheet. Nat. Commun. 12, 570. https://doi.org/10.1038/s41467-020-

$116120627-w$

1162 McLaughlin, J.B., Gessner, B.D., Bailey, A.M., 2005. Gastroenteritis outbreak among

1163 mountaineers climbing the West Buttress route of Denali-Denali National Park, Alaska,

1164 June 2002. Wilderness Environ. Med. 16, 92-96.

1165 Milner, A.M., Khamis, K., Battin, T.J., Brittain, J.E., Barrand, N.E., Füreder, L., Cauvy-Fraunié,

1166 S., Gíslason, G.M., Jacobsen, D., Hannah, D.M., Hodson, A.J., Hood, E., Lencioni, V.,

1167 Ólafsson, J.S., Robinson, C.T., Tranter, M., Brown, L.E., 2017. Glacier shrinkage driving

1168 global changes in downstream systems. Proc. Natl. Acad. Sci. U. S. A. 114, 9770-9778.

1169 https://doi.org/10.1073/pnas.1619807114

1170 Mizuno, K., 2005. Glacial fluctuation and vegetation succession on Tyndall Glacier, Mt Kenya.

1171 Mt. Res. Dev. 25, 68-75.

1172 Murakami, T., Segawa, T., Bodington, D., Dial, R., Takeuchi, N., Kohshima, S., Hongoh, Y.,

1173 2015. Census of bacterial microbiota associated with the glacier ice worm

1174 Mesenchytraeus solifugus. FEMS Microbiol. Ecol. 91.

1175 https://doi.org/10.1093/femsec/fiv003 
1176 Musilova, M., Tranter, M., Bamber, J.L., Takeuchi, N., Anesio, A., 2016. Experimental evidence 1177 that microbial activity lowers the albedo of glaciers. Geochem. Perspect. Lett. 106-116. 1178 https://doi.org/10.7185/geochemlet.1611

1179 Nedbalová, L., P, S., 2008. New records of snow algae from the Andes of Ecuador. Arnaldoa $1180 \quad 15,17-20$.

1181 Onuma, Y., Takeuchi, N., Tanaka, S., Nagatsuka, N., Niwano, M., Aoki, T., 2020. Physically 1182 based model of the contribution of red snow algal cells to temporal changes in albedo in 1183 northwest Greenland. Cryosphere 14, 2087-2101. https://doi.org/10.5194/tc-14-2087$1184 \quad 2020$

1185 Onuma, Y., Takeuchi, N., Tanaka, S., Nagatsuka, N., Niwano, M., Aoki, T., 2018. Observations 1186 and modelling of algal growth on a snowpack in north-western Greenland. The 1187 Cryosphere 12, 2147-2158. https://doi.org/10.5194/tc-12-2147-2018 1188 Painter, T.H., Barrett, A.P., Landry, C.C., Neff, J.C., Cassidy, M.P., Lawrence, C.R., McBride, 1189 K.E., Farmer, G.L., 2007. Impact of disturbed desert soils on duration of mountain snow 1190 cover. Geophys. Res. Lett. 34. https://doi.org/10.1029/2007gl030284

1191 Painter, T.H., Duval, B., Thomas, W.H., Mendez, M., Heintzelman, S., Dozier, J., 2001. 1192 Detection and Quantification of Snow Algae with an Airborne Imaging Spectrometer. 1193 Appl. Environ. Microbiol. 67, 5267-5272. https://doi.org/10.1128/aem.67.11.5267$1194 \quad 5272.2001$

1195 Parmesan, C., 2006. Ecological and Evolutionary Responses to Recent Climate Change. Annu. 1196 Rev. Ecol. Evol. Syst. 37, 637-669. https://doi.org/10.1146/annurev.ecolsys.37.091305.110100

1198 Perini, L., Gostinčar, C., Anesio, A.M., Williamson, C., Tranter, M., Gunde-Cimerman, N., 2019. 1199 Darkening of the Greenland ice sheet: Fungal abundance and diversity are associated 1200 with algal bloom. Front. Microbiol. 10. https://doi.org/10.3389/fmicb.2019.00557 
1201 Pfeffer, W.T., Arendt, A.A., Bliss, A., Bolch, T., Cogley, J.G., Gardner, A.S., Hagen, J.-O., Hock,

1202

1203

1204

1205

1206

1207

1208

1209

1210

1211

1212

1213

1214

1215

1216

1217

1218

1219

1220

1221

1222

1223

1224

1225

R., Kaser, G., Kienholz, C., Miles, E.S., Moholdt, G., Mölg, N., Paul, F., Radić, V., Rastner, P., Raup, B.H., Rich, J., Sharp, M.J., The Randolph Consortium, 2014. The Randolph Glacier Inventory: a globally complete inventory of glaciers. J. Glaciol. 60, 537-552. https://doi.org/10.3189/2014JoG13J176

Phillips-Lander, C.M., Harrold, Z., Hausrath, E.M., Lanzirotti, A., Newville, M., Adcock, C.T., Raymond, J.A., Huang, S., Tschauner, O., Sanchez, A., 2020. Snow Algae Preferentially Grow on Fe-containing Minerals and Contribute to the Formation of Fe Phases. Geomicrobiol. J. 1-10. https://doi.org/10.1080/01490451.2020.1739176

Pickering, C.M., Barros, A., 2015. Environmental impacts of mountaineering. Mt. Tour. 245-275. https://doi.org/10.4324/9781315769202-26

Pramanik, P., Ghosh, G.K., Ghosal, P.K., Banik, P., 2007. Changes in organic - C, N, P and K and enzyme activities in vermicompost of biodegradable organic wastes under liming and microbial inoculants. Bioresour. Technol. 98, 2485-2494. https://doi.org/10.1016/j.biortech.2006.09.017

Procházková, L., Leya, T., Křržzová, H., Nedbalová, L., 2019. Sanguina nivaloides and Sanguina aurantia gen. et spp. nov. (Chlorophyta): the taxonomy, phylogeny, biogeography and ecology of two newly recognised algae causing red and orange snow. FEMS Microbiol. Ecol. 95. https://doi.org/10.1093/femsec/fiz064

Quinn, P.K., Collins, D.B., Grassian, V.H., Prather, K.A., Bates, T.S., 2015. Chemistry and Related Properties of Freshly Emitted Sea Spray Aerosol. Chem. Rev. 115, 4383-4399. https://doi.org/10.1021/cr500713g

Reckin, R., 2013. Ice Patch Archaeology in Global Perspective: Archaeological Discoveries from Alpine Ice Patches Worldwide and Their Relationship with Paleoclimates. J. World Prehistory 26, 323-385. https://doi.org/10.1007/s10963-013-9068-3 
1226 Remias, D., Holzinger, A., Aigner, S., Lütz, C., 2012. Ecophysiology and ultrastructure of Ancylonema nordenskiöldii (Zygnematales, Streptophyta), causing brown ice on glaciers in Svalbard (high arctic). Polar Biol. 35, 899-908. https://doi.org/10.1007/s00300-011$1135-6$

Remias, D., Holzinger, A., Lutz, C., 2009. Physiology, ultrastructure and habitat of the ice alga Mesotaenium berggrenii (Zygnemaphyceae, Chlorophyta) from glaciers in the European Alps. Phycologia 48, 302-312. https://doi.org/10.2216/08-13.1

Remias, D., Lütz-Meindl, U., Lütz, C., 2005. Photosynthesis, pigments and ultrastructure of the alpine snow alga Chlamydomonas nivalis. Eur. J. Phycol. 40, 259-268. https://doi.org/10.1080/09670260500202148

Remias, D., Schwaiger, S., Aigner, S., Leya, T., Stuppner, H., Lütz, C., 2011. Characterization of an UV- and VIS-absorbing, purpurogallin-derived secondary pigment new to algae and highly abundant in Mesotaenium berggrenii (Zygnematophyceae, Chlorophyta), an extremophyte living on glaciers. FEMS Microbiol. Ecol. 79, 638-648. https://doi.org/10.1111/j.1574-6941.2011.01245.x

Remias, D., Wastian, H., Lütz, C., Leya, T., 2013. Insights into the biology and phylogeny of Chloromonas polyptera (Chlorophyta), an alga causing orange snow in Maritime Antarctica. Antarct. Sci. 25, 648-656. https://doi.org/10.1017/S0954102013000060

Remias, R., 2012. Cell structure and physiology of alpine snow and glacier algae. pp. 175-185. https://doi.org/10.1007/978-3-7091-0136-0_13

Ren, Z., Martyniuk, N., Oleksy, I.A., Swain, A., Hotaling, S., 2019. Ecological Stoichiometry of the Mountain Cryosphere. Front. Ecol. Evol. 7, 360-360. https://doi.org/10.3389/fevo.2019.00360

Resano-Mayor, J., Korner-Nievergelt, F., Vignali, S., Horrenberger, N., Barras, A.G., Braunisch, V., Pernollet, C.A., Arlettaz, R., 2019. Snow cover phenology is the main driver of foraging habitat selection for a high-alpine passerine during breeding: implications for 
species persistence in the face of climate change. Biodivers. Conserv. 28, 2669-2685. https://doi.org/10.1007/s10531-019-01786-9

1254 Rosvold, J., 2015. Perennial ice and snow-covered land as important ecosystems for birds and mammals. J. Biogeogr. 43, 3-12. https://doi.org/10.1111/jbi.12609

1256

1257

1258

1259

1260

1261

1262

1263

1264

1265

1266

1267

1268

1269

1270

1271

1272

1273

1274

1275

\author{
mammals. J. Biogeogr. 43, 3-12. https://doi.org/10.1111/jbi.12609
}

Ryan, J.C., Hubbard, A., Stibal, M., Irvine-Fynn, T.D., Cook, J., Smith, L.C., Cameron, K., Box, J., 2018. Dark zone of the Greenland Ice Sheet controlled by distributed biologicallyactive impurities. Nat. Commun. 9, 1065-1065. https://doi.org/10.1038/s41467-01803353-2

Sanchez-Bayo, F., Wyckhuys, K.A.G., 2019. Response to "Global insect decline: Comments on Sánchez-Bayo and Wyckhuys (2019)." Biol. Conserv. 233, 334-335. https://doi.org/10.1016/j.biocon.2019.03.020

Segawa, T., Matsuzaki, R., Takeuchi, N., Akiyoshi, A., Navarro, F., Sugiyama, S., Yonezawa, T., Mori, H., 2018. Bipolar dispersal of red-snow algae. Nat. Commun. 9, 3094-3094. https://doi.org/10.1038/s41467-018-05521-w

Segawa, T., Takeuchi, N., 2010. Cyanobacterial communities on Qiyi glacier, Qilian Shan, China. Ann. Glaciol. 51, 135-144. https://doi.org/10.3189/172756411795932047

Segawa, T., Yonezawa, T., Edwards, A., Akiyoshi, A., Tanaka, S., Uetake, J., Irvine-Fynn, T., Fukui, K., Li, Z., Takeuchi, N., 2017. Biogeography of cryoconite forming cyanobacteria on polar and Asian glaciers. J. Biogeogr. 44, 2849-2861. https://doi.org/10.1111/jbi.13089

Shain, D.H., Halldórsdóttir, K., Pálsson, F., Adalgeirsdóttir, G., Gunnarsson, A., Jónsson, T., Lang, S.A., Pálsson, H.S., Steinthórssson, S., Arnason, E., 2016. Colonization of maritime glacier ice by bdelloid Rotifera. Mol. Phylogenet. Evol. 98, 280-287. https://doi.org/10.1016/j.ympev.2016.02.020 
1276 Shain, D.H., Mason, T.A., Farrell, A.H., Michalewicz, L.A., 2001. Distribution and behavior of ice worms ( Mesenchytraeus solifugus ) in south-central Alaska. Can. J. Zool. 79, 18131821. https://doi.org/10.1139/z01-143

1279

1280

1281

1282

1283

1284

1285

1286

1287

1288

1289

1290

1291

1292

1293

1294

1295

1296

1297

1298

1299

1300

1301

Skiles, S.M., Flanner, M., Cook, J.M., Dumont, M., Painter, T.H., 2018. Radiative forcing by light-absorbing particles in snow. Nat. Clim. Change 8, 964-971. https://doi.org/10.1038/s41558-018-0296-5

Skiles, S.M., Painter, T., 2017. Daily evolution in dust and black carbon content, snow grain size, and snow albedo during snowmelt, Rocky Mountains, Colorado. J. Glaciol. 63, 118-132. https://doi.org/10.1017/jog.2016.125

Skiles, S.M., Painter, T.H., Belnap, J., Holland, L., Reynolds, R.L., Goldstein, H.L., Lin, J., 2015. Regional variability in dust-on-snow processes and impacts in the Upper Colorado River Basin. Hydrol. Process. 29, 5397-5413. https://doi.org/10.1002/hyp.10569

Small, G.E., Torres, P.J., Schweizer, L.M., Duff, J.H., Pringle, C.M., 2013. Importance of Terrestrial Arthropods as Subsidies in Lowland Neotropical Rain Forest 45, 80-87. https://doi.org/10.1111/j.1744-7429.2012.00896.x

Spalding, J.B., 1979. The Aeolian Ecology of White Mountain Peak, California: Windblown Insect Fauna. Arct. Alp. Res. 11, 83. https://doi.org/10.2307/1550461

Spijkerman, E., Wacker, A., Weithoff, G., Leya, T., 2012. Elemental and fatty acid composition of snow algae in Arctic habitats. https://doi.org/10.3389/fmicb.2012.00380

Stevens, V., 1979. Mountain goat (Oreamnos americanus) habitat utilization in Olympic Park.

Stevens-Rumann, C.S., Kemp, K.B., Higuera, P.E., Harvey, B.J., Rother, M.T., Donato, D.C., Morgan, P., Veblen, T.T., 2018. Evidence for declining forest resilience to wildfires under climate change. Ecol. Lett. 21, 243-252. https://doi.org/10.1111/ele.12889

Stibal, M., Anesio, A.M., Blues, C.J.D., Tranter, M., 2009. Phosphatase activity and organic phosphorus turnover on a high Arctic glacier. Biogeosciences 6, 913-922. https://doi.org/10.5194/bg-6-913-2009 
1302

1303

1304

1305

1306

1307

1308

1309

1310

1311

1312

1313

1314

1315

1316

1317

1318

1319

1320

1321

1322

1323

1324

1325

1326

Stibal, M., Box, J.E., Cameron, K.A., Langen, P.L., Yallop, M.L., Mottram, R.H., Khan, A.L., Molotch, N.P., Chrismas, N.A.M., Quaglia, F.C., Remias, D., Smeets, C.J.P.P., Broeke, M.R., Ryan, J.C., Hubbard, A., Tranter, M., As, D., Ahlstrøm, A.P., 2017. Algae Drive Enhanced Darkening of Bare Ice on the Greenland Ice Sheet. Geophys. Res. Lett. 44, 11,411-463,471. https://doi.org/10.1002/2017gl075958

Stibal, M., Bradley, J.A., Edwards, A., Hotaling, S., Zawierucha, K., Rosvold, J., Lutz, S., Cameron, K.A., Mikucki, J.A., Kohler, T.J., Šabacká, M., Anesio, A.M., 2020. Glacial ecosystems are essential to understanding biodiversity responses to glacier retreat. Nat. Ecol. Evol. 4, 686-687. https://doi.org/10.1038/s41559-020-1163-0

Stibal, M., Gözdereliler, E., Cameron, K.A., Box, J.E., Stevens, I.T., Gokul, J.K., Schostag, M., Zarsky, J.D., Edwards, A., Irvine-Fynn, T.D.L., Jacobsen, C.S., 2015. Microbial abundance in surface ice on the Greenland Ice Sheet. Front. Microbiol. 6, 225-225. https://doi.org/10.3389/fmicb.2015.00225

Stibal, M., Šabacká, M., Žárský, J., 2012. Biological processes on glacier and ice sheet surfaces. Nat. Geosci. 5, 771-774. https://doi.org/10.1038/ngeo1611

Swan, L.W., 1963. Aeolian Zone. Science 140, 77-78. https://doi.org/10.1126/science.140.3562.77

Sydeman, W.J., García-Reyes, M., Schoeman, D.S., Rykaczewski, R.R., Thompson, S.A., Black, B.A., Bograd, S.J., 2014. Climate change and wind intensification in coastal upwelling ecosystems. Science 345, 77-80. https://doi.org/10.1126/science.1251635

Takaichi, S., 2011. Carotenoids in algae: Distributions, biosyntheses and functions. Mar. Drugs 9, 1101-1118. https://doi.org/10.3390/md9061101

Takeuchi, N., 2013. Seasonal and altitudinal variations in snow algal communities on an Alaskan glacier (Gulkana glacier in the Alaska range). Environ. Res. Lett. 8, 3500235002. https://doi.org/10.1088/1748-9326/8/3/035002 
1327 Takeuchi, N., 2009. Temporal and spatial variations in spectral reflectance and characteristics of surface dust on Gulkana Glacier, Alaska Range. J. Glaciol. 55, 701-709. https://doi.org/10.3189/002214309789470914

Takeuchi, N., 2002. Optical characteristics of cryoconite (surface dust) on glaciers: the

\section{3}

1334

1335

1336

1337

1338

1339

1340

1341

1342

1343

1344

1345

1346

1347

1348

1349

1350

1351

1352 relationship between light absorbency and the property of organic matter contained in the cryoconite. Ann. Glaciol. 34, 409-414. https://doi.org/10.3189/172756402781817743

Takeuchi, N., Dial, R., Kohshima, S., Segawa, T., Uetake, J., 2006. Spatial distribution and abundance of red snow algae on the Harding Icefield, Alaska derived from a satellite image. Geophys. Res. Lett. 33. https://doi.org/10.1029/2006gl027819

Takeuchi, N., Kohshima, S., 2004. A Snow Algal Community on Tyndall Glacier in the Southern Patagonia Icefield, Chile. Arct. Antarct. Alp. Res. 36, 92-99.

Takeuchi, N., Kohshima, S., Seko, K., 2001a. Structure, Formation, and Darkening Process of Albedo-reducing Material (Cryoconite) on a Himalayan Glacier: A Granular Algal Mat Growing on the Glacier. Arct. Antarct. Alp. Res. 33, 115-122.

Takeuchi, N., Kohshima, S., Seko, K., 2001b. Structure, Formation, and Darkening Process of Albedo-reducing Material (Cryoconite) on a Himalayan Glacier: A Granular Algal Mat Growing on the Glacier. Arct. Antarct. Alp. Res. 33, 115-122. https://doi.org/10.1080/15230430.2001.12003413

Takeuchi, N., Sakaki, R., Uetake, J., Nagatsuka, N., Shimada, R., Niwano, M., Aoki, T., 2018. Temporal variations of cryoconite holes and cryoconite coverage on the ablation ice surface of Qaanaaq Glacier in northwest Greenland. Ann. Glaciol. 59, 21-30. https://doi.org/10.1017/aog.2018.19

Tamaru, Y., Takani, Y., Yoshida, T., Sakamoto, T., 2005. Crucial Role of Extracellular Polysaccharides in Desiccation and Freezing Tolerance in the Terrestrial Cyanobacterium Nostoc commune. Appl. Environ. Microbiol. 71, 7327-7333. https://doi.org/10.1128/aem.71.11.7327-7333.2005 
1353 Tanaka, S., Takeuchi, N., Miyairi, M., Fujisawa, Y., Kadota, T., Shirakawa, T., Kusaka, R., Takahashi, S., Enomoto, H., Ohata, T., Yabuki, H., Konya, K., Fedorov, A., Konstantinov, P., 2016. Snow algal communities on glaciers in the Suntar-Khayata Mountain Range in eastern Siberia, Russia. Polar Sci. 10, 227-238. https://doi.org/10.1016/j.polar.2016.03.004

Tedstone, A.J., Bamber, J.L., Cook, J.M., Williamson, C.J., Fettweis, X., Hodson, A.J., Tranter, M., 2017. Dark ice dynamics of the south-west Greenland Ice Sheet. The Cryosphere 11, 2491-2506. https://doi.org/10.5194/tc-11-2491-2017

Telling, J., Anesio, A.M., Tranter, M., Irvine-Fynn, T., Hodson, A., Butler, C., Wadham, J., 2011. Nitrogen fixation on Arctic glaciers, Svalbard. J. Geophys. Res. 116, G03039-G03039. https://doi.org/10.1029/2010JG001632

Telling, J., Stibal, M., Anesio, A.M., Tranter, M., Nias, I., Cook, J., Bellas, C., Lis, G., Wadham, J.L., Sole, A., Nienow, P., Hodson, A., 2012. Microbial nitrogen cycling on the Greenland Ice Sheet. Biogeosciences 9, 2431-2442. https://doi.org/10.5194/bg-9-2431-2012

Thackeray, C.W., Derksen, C., Fletcher, C.G., Hall, A., 2019. Snow and Climate: Feedbacks,

Thesiger, W., 1970. Wild dog at 5894 m (19,340 ft). Afr. J. Ecol. 8, 202-203.

1371 Thomas, W.H., Duval, B., 1995. Sierra Nevada, California, U.S.A., Snow Algae: Snow Albedo Changes, Algal-Bacterial Interrelationships, and Ultraviolet Radiation Effects. Arct. Alp.

1374 Uetake, J., Tanaka, S., Hara, K., Tanabe, Y., Samyn, D., Motoyama, H., Imura, S., Kohshima, 1375 S., 2014. Novel Biogenic Aggregation of Moss Gemmae on a Disappearing African Glacier. PLoS ONE 9, e112510-e112510. https://doi.org/10.1371/journal.pone.0112510 
Veettil, B.K., Kamp, U., 2019. Global Disappearance of Tropical Mountain Glaciers: Observations, Causes, and Challenges. Geosciences 9, 1-25. https://doi.org/10.3390/geosciences9050196

Vera, A., Zuñiga-Reinoso, A., Muñoz-Escobar, C., 2012. Historical Perspective on the Distribution of Andiperla Willinki "Patagonian Dragon” (Plecoptera: Gripopterygidae). Rev Chil. Ent 37, 87-93.

Verbeek, N.A., 1970. Breeding ecology of the Water Pipit. The Auk 87, 425-451.

von Humboldt, A., 1808. Ansichten der Natur mit wissenschaftlichen Erläuterungen. Stuttgart, Germany.

Weinbauer, M.G., 2004. Ecology of prokaryotic viruses. FEMS Microbiol. Rev. 28, 127-181.

Williamson, C.J., Cameron, K.A., Cook, J.M., Zarsky, J.D., Stibal, M., Edwards, A., 2019. Glacier Algae: A Dark Past and a Darker Future. Front. Microbiol. 10, 524-524.

Williamson, C.J., Cook, J., Tedstone, A., Yallop, M., McCutcheon, J., Poniecka, E., Campbell, D., Irvine-Fynn, T., McQuaid, J., Tranter, M., Perkins, R., Anesio, A., 2020. Algal photophysiology drives darkening and melt of the Greenland Ice Sheet. Proc. Natl. Acad. Sci. 117, 5694-5705. https://doi.org/10.1073/pnas.1918412117

Winski, D., Osterberg, E., Ferris, D., Kreutz, K., Wake, C., Campbell, S., Hawley, R., Roy, S., Birkel, S., Introne, D., Handley, M., 2017. Industrial-age doubling of snow accumulation in the Alaska Range linked to tropical ocean warming. Sci. Rep. 7, 17869-17869.

Wiscombe, W.J., Warren, S.G., 1980. A Model for Spectral Albedo of Snow- Pure Snow. J. Atmospheric Sci. 37, 2712-2745.

Yallop, M.L., Anesio, A.M., Perkins, R.G., Cook, J., Telling, J., Fagan, D., MacFarlane, J., Stibal, M., Barker, G., Bellas, C., Hodson, A., Tranter, M., Wadham, J., Roberts, N.W., 2012. Photophysiology and albedo-changing potential of the ice algal community on the surface of the Greenland ice sheet. ISME J. 6, 2302-2313. https://doi.org/10.1038/ismej.2012.107 
1403 Yang, L.H., Gratton, C., 2014. Insects as drivers of ecosystem processes. Curr. Opin. Insect 1404 Sci. https://doi.org/10.1016/j.cois.2014.06.004

1405 Yoshimura, Y., Kohshima, S., Ohtani, S., 1997. A Community of Snow Algae on a Himalayan $1406 \quad$ Glacier: Change of Algal Biomass and Community Structure with Altitude. Arct. Alp. Res. $140729,126-126$. https://doi.org/10.2307/1551843

1408 Zawierucha, K., Shain, D.H., 2019. Disappearing Kilimanjaro snow-Are we the last generation 1409 to explore equatorial glacier biodiversity? Ecol. Evol. 9, 8911-8918.

1410 https://doi.org/10.1002/ece3.5327

1411 Zawierucha, K., Stec, D., Lachowska-Cierlik, D., Takeuchi, N., Li, Z., Michalczyk, Ł., 2018. High

1412 Mitochondrial Diversity in a New Water Bear Species (Tardigrada: Eutardigrada) from

1413 Mountain Glaciers in Central Asia, with the Erection of a New Genus Cryoconicus. Ann.

1414 Zool. 68, 179-201. https://doi.org/10.3161/00034541ANZ2018.68.1.007

1415 Zemp, M., Huss, M., Thibert, E., Eckert, N., McNabb, R., Huber, J., Barandun, M., Machguth, 1416 H., Nussbaumer, S.U., Gärtner-Roer, I., Thomson, L., Paul, F., Maussion, F., Kutuzov, S., Cogley, J.G., 2019. Global glacier mass changes and their contributions to sea-level rise from 1961 to 2016 . Nature 568, 382-386.

Zhang, Z., Qu, C., Zhang, K., He, Y., Zhao, X., Yang, L., Zheng, Z., Ma, X., Wang, X., Wang, W., Wang, K., Li, D., Zhang, L., Zhang, X., Su, D., Chang, X., Zhou, M., Gao, D., Jiang, W., Leliaert, F., Bhattacharya, D., De Clerck, O., Zhong, B., Miao, J., 2020. Adaptation to Extreme Antarctic Environments Revealed by the Genome of a Sea Ice Green Alga. Curr. Biol. 30, 3330-3341.e7. 